\title{
Complete Stereochemical Assignment of Campechic Acids A and B
}

Ruri Isaka, ${ }^{\dagger}$ Linkai Yu, ${ }^{\ddagger}$ Makoto Sasaki, ${ }^{\dagger}$ Yasuhiro Igarashi, ${ }^{\ddagger}$ and Haruhiko Fuwa ${ }^{* \dagger}$

${ }^{\dagger}$ Graduate School of Life Sciences, Tohoku University, 2-1-1 Katahira, Aoba-ku, Sendai 980-8577, Japan

${ }^{\ddagger}$ Biotechnology Research Center and Department of Biotechnology, Toyama Prefectural University, 5180 Kurokawa, Imizu, Toyama 939-0398, Japan

*Corresponding author: hfuwa@m.tohoku.ac.jp 


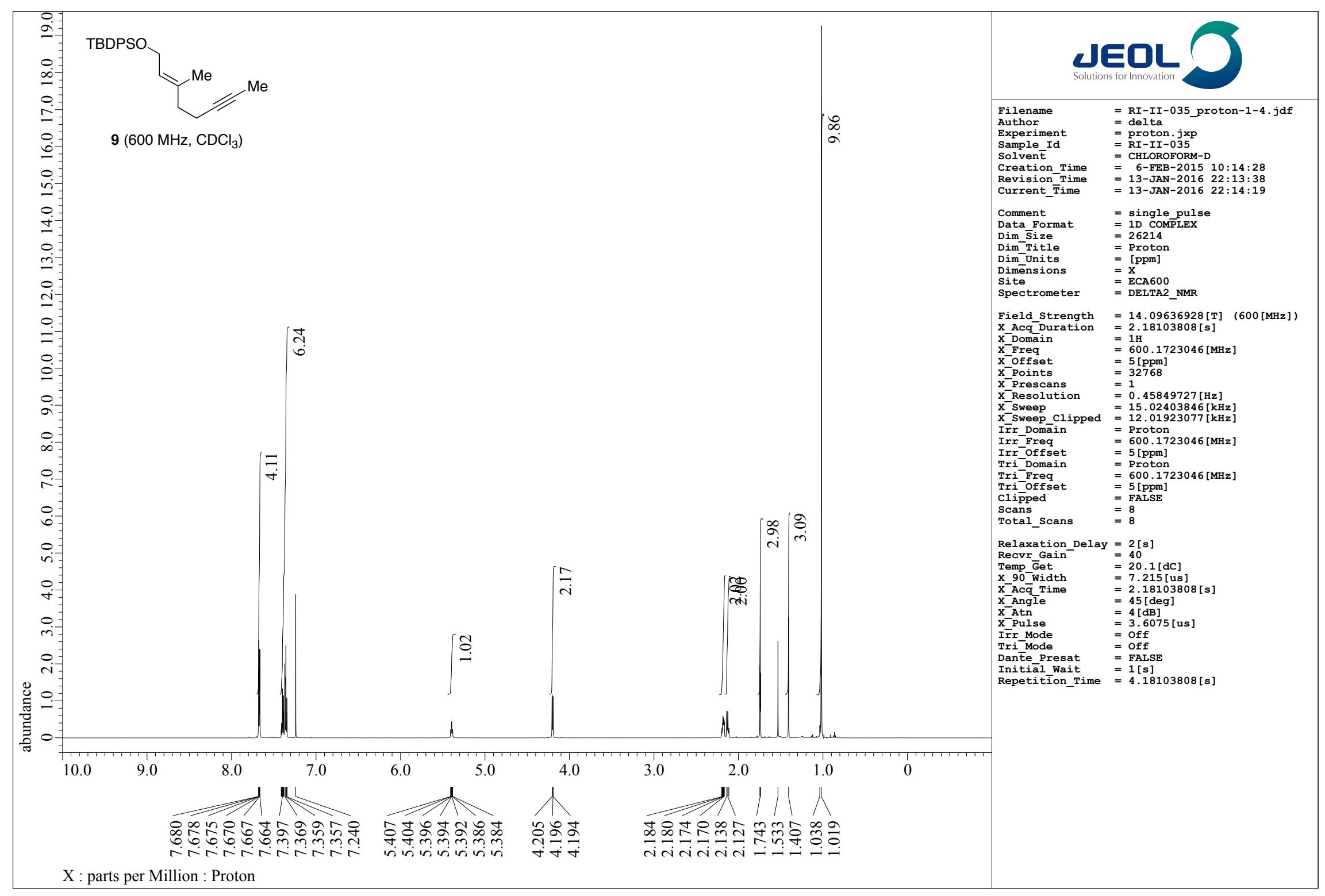




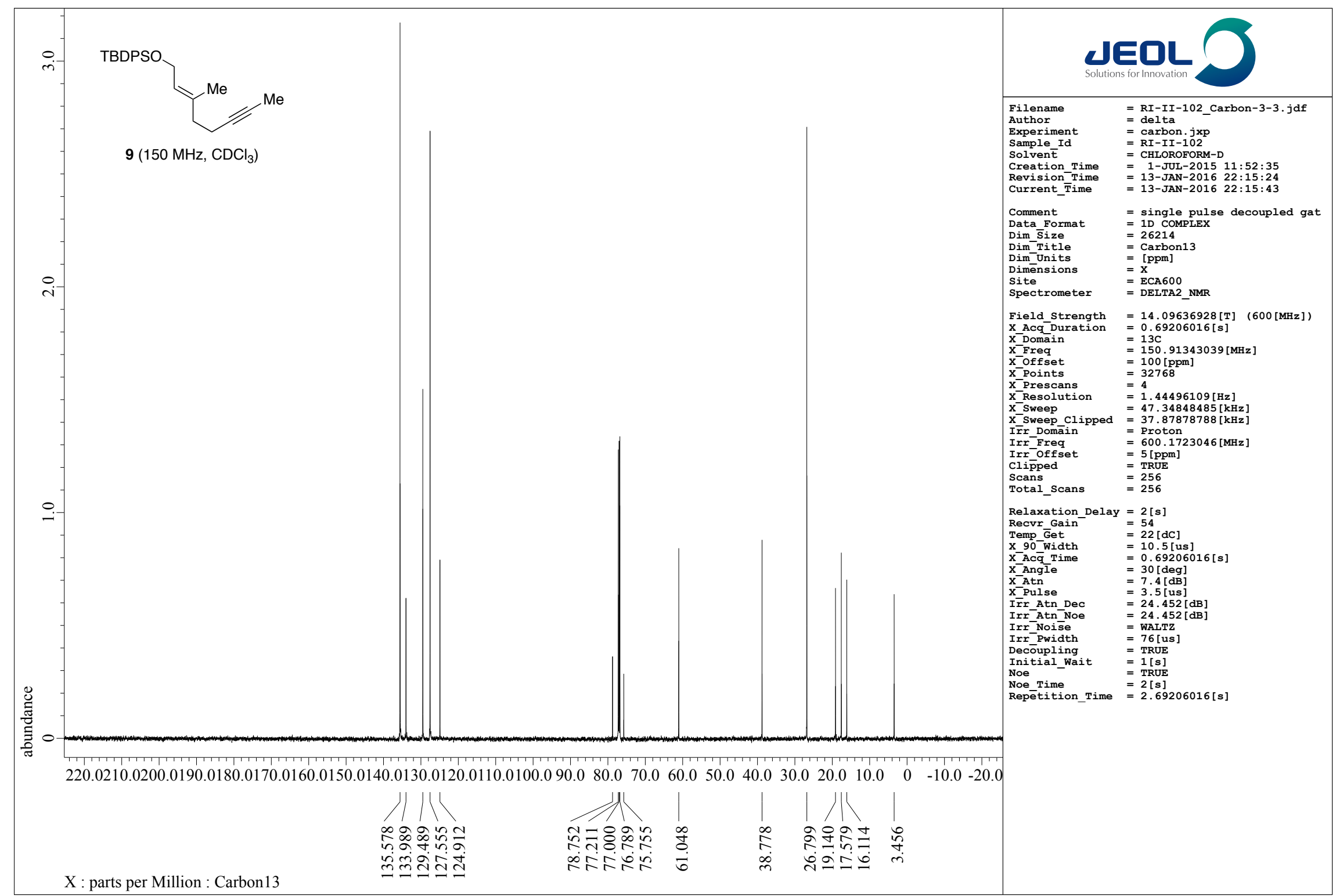




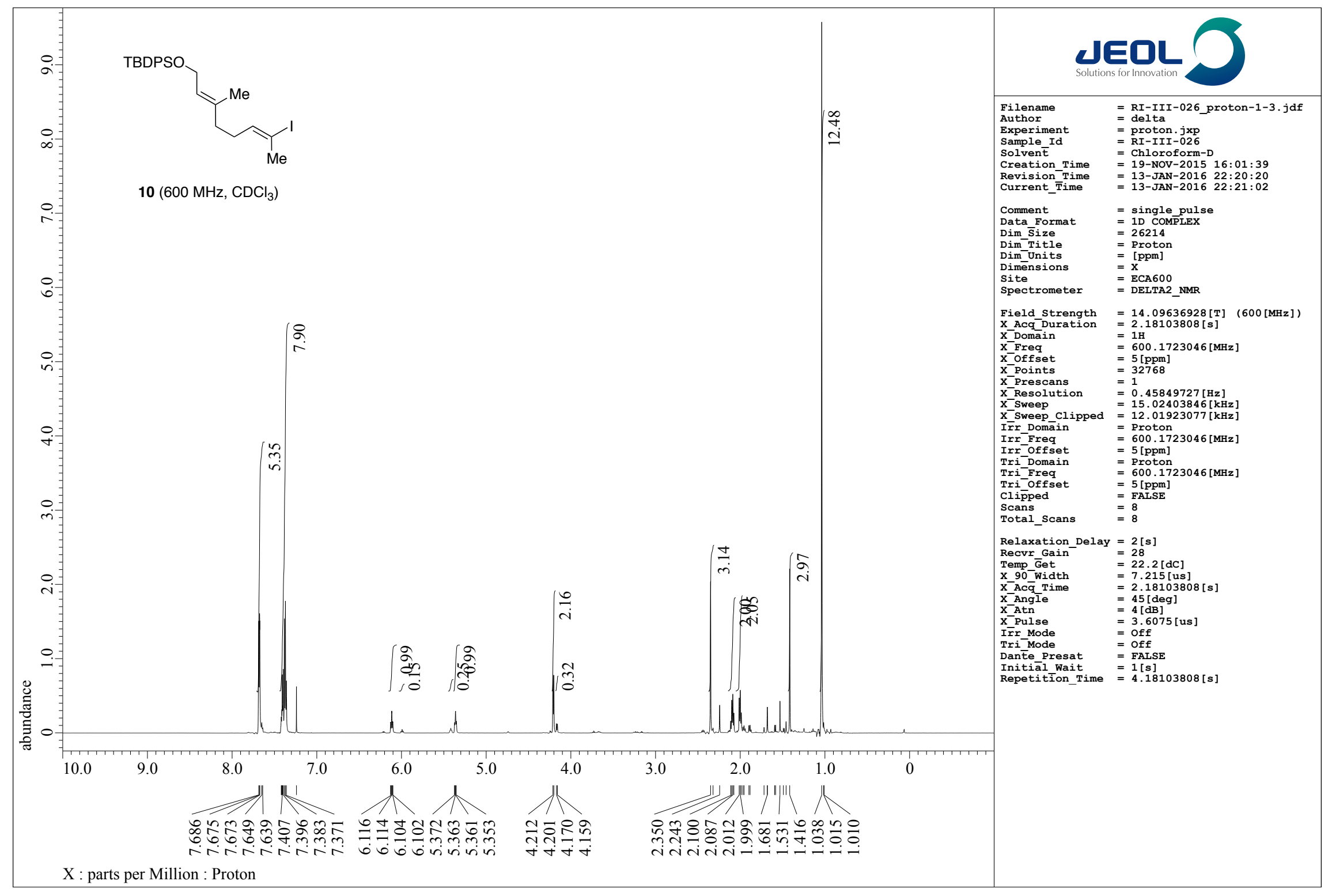




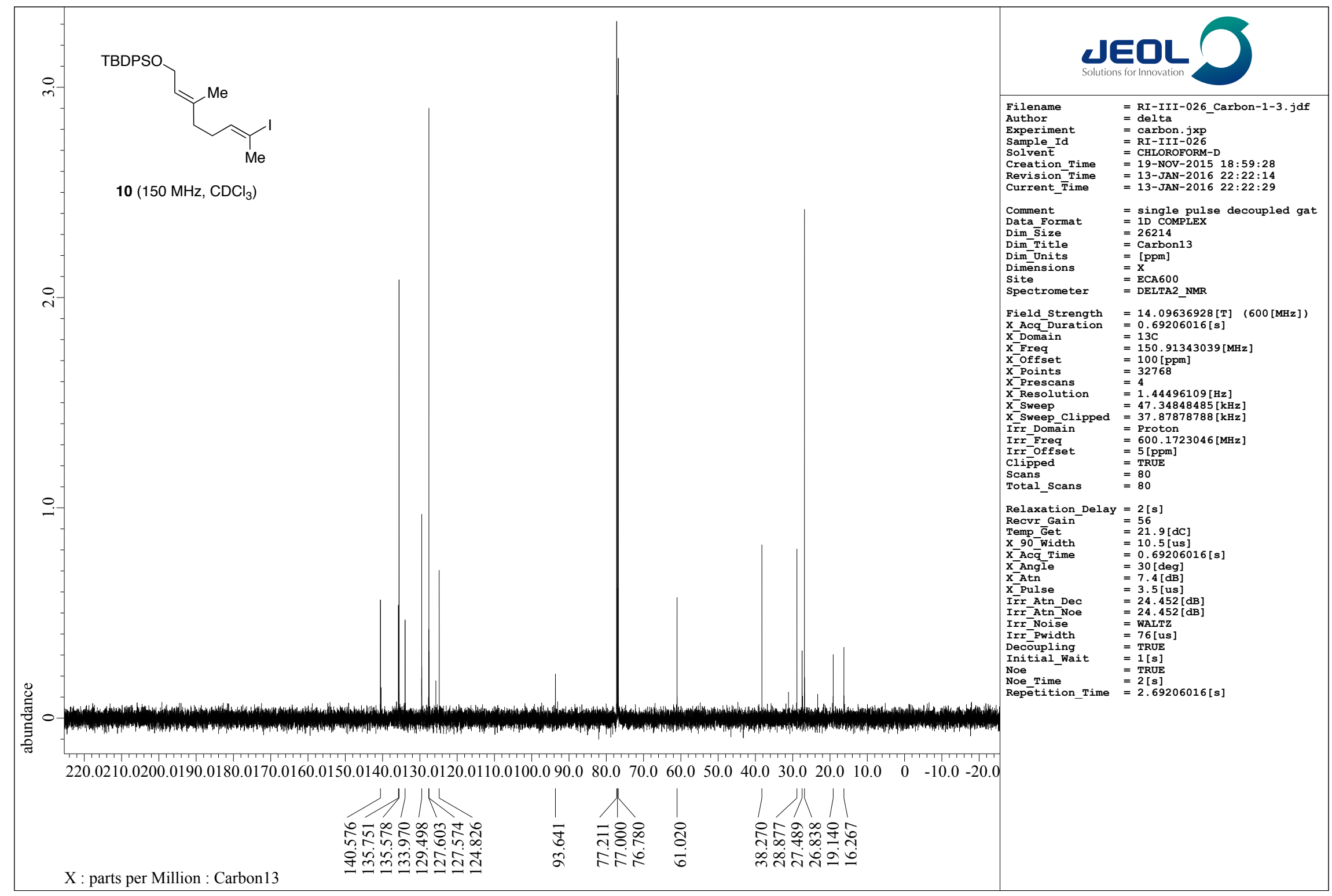




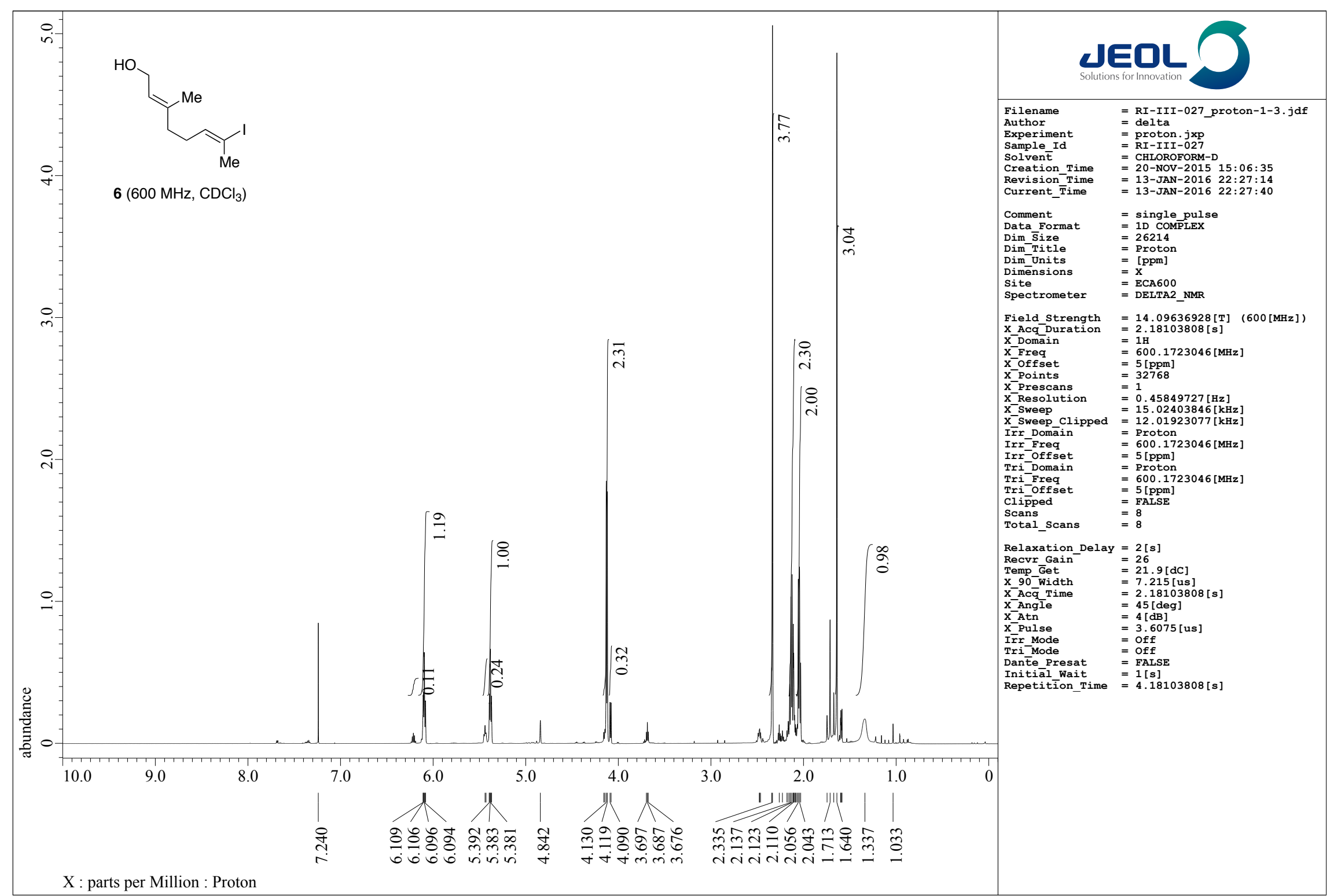




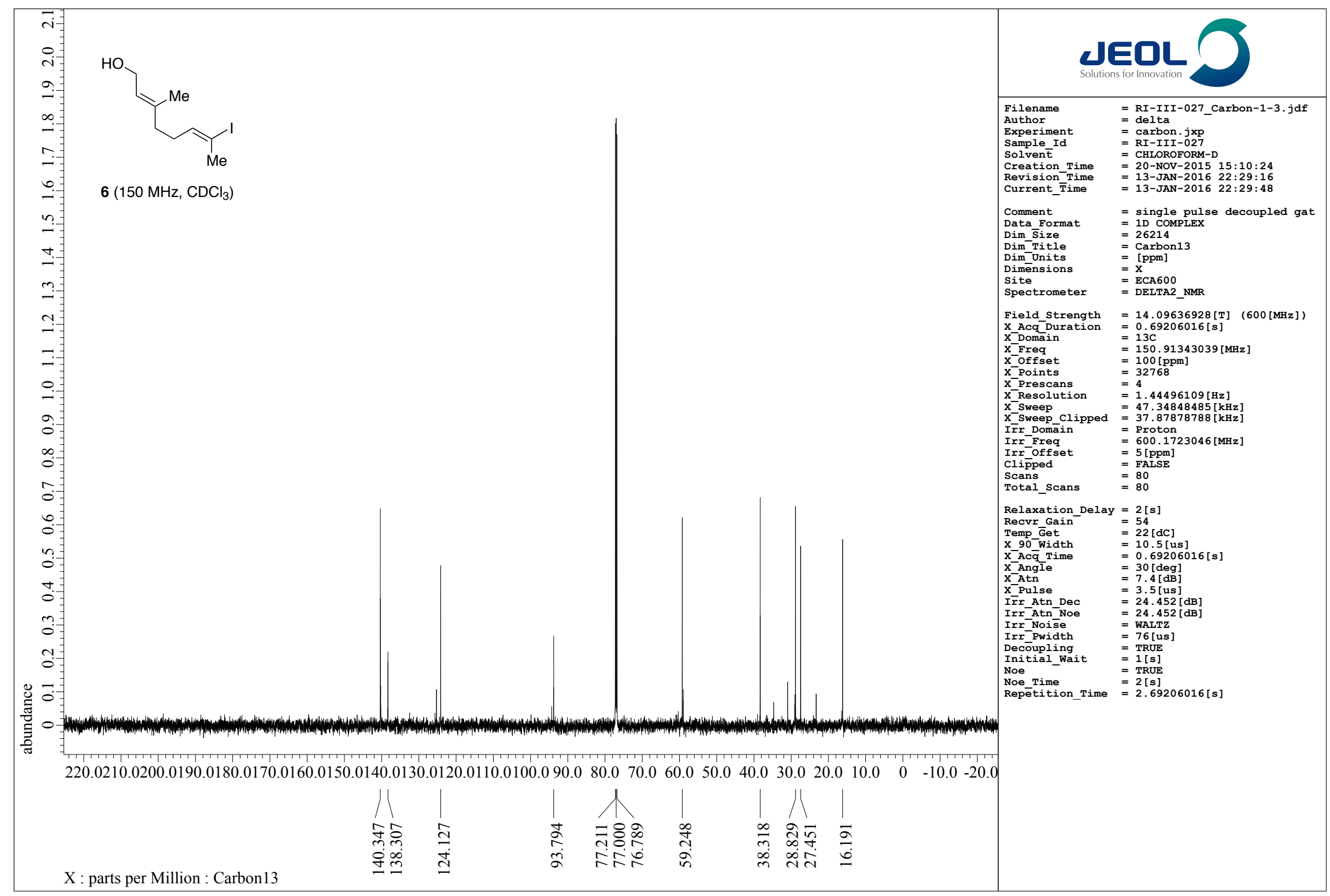




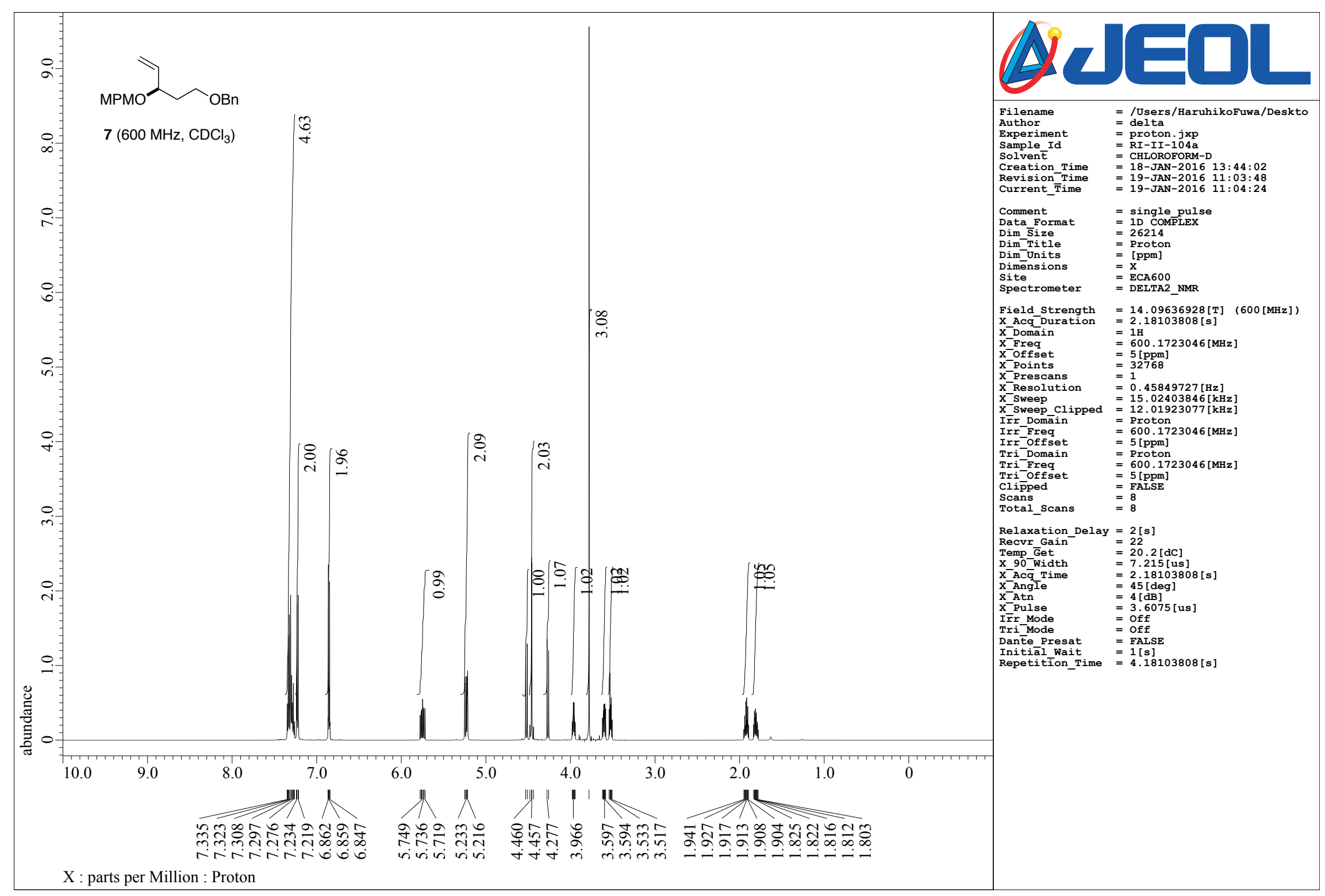




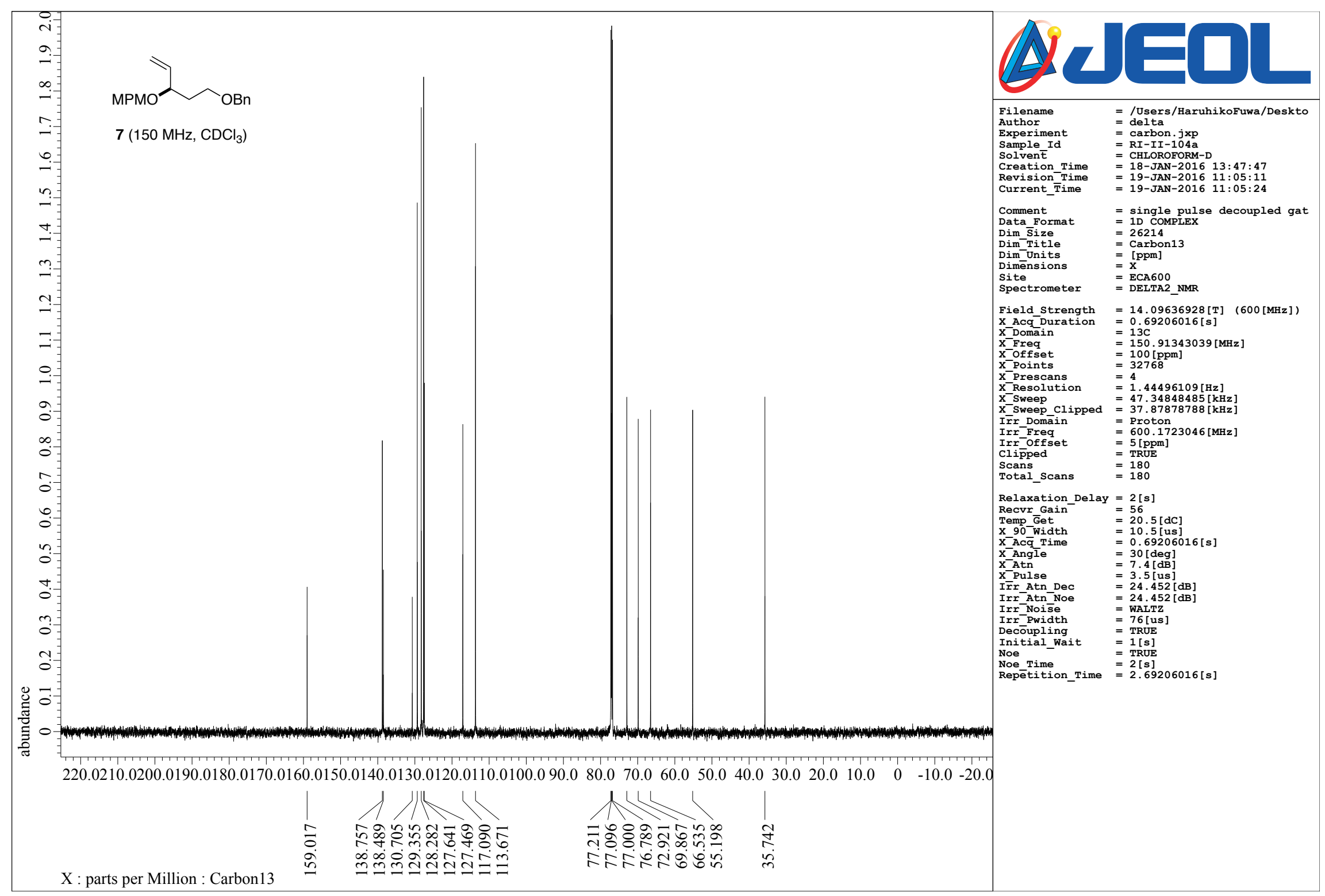




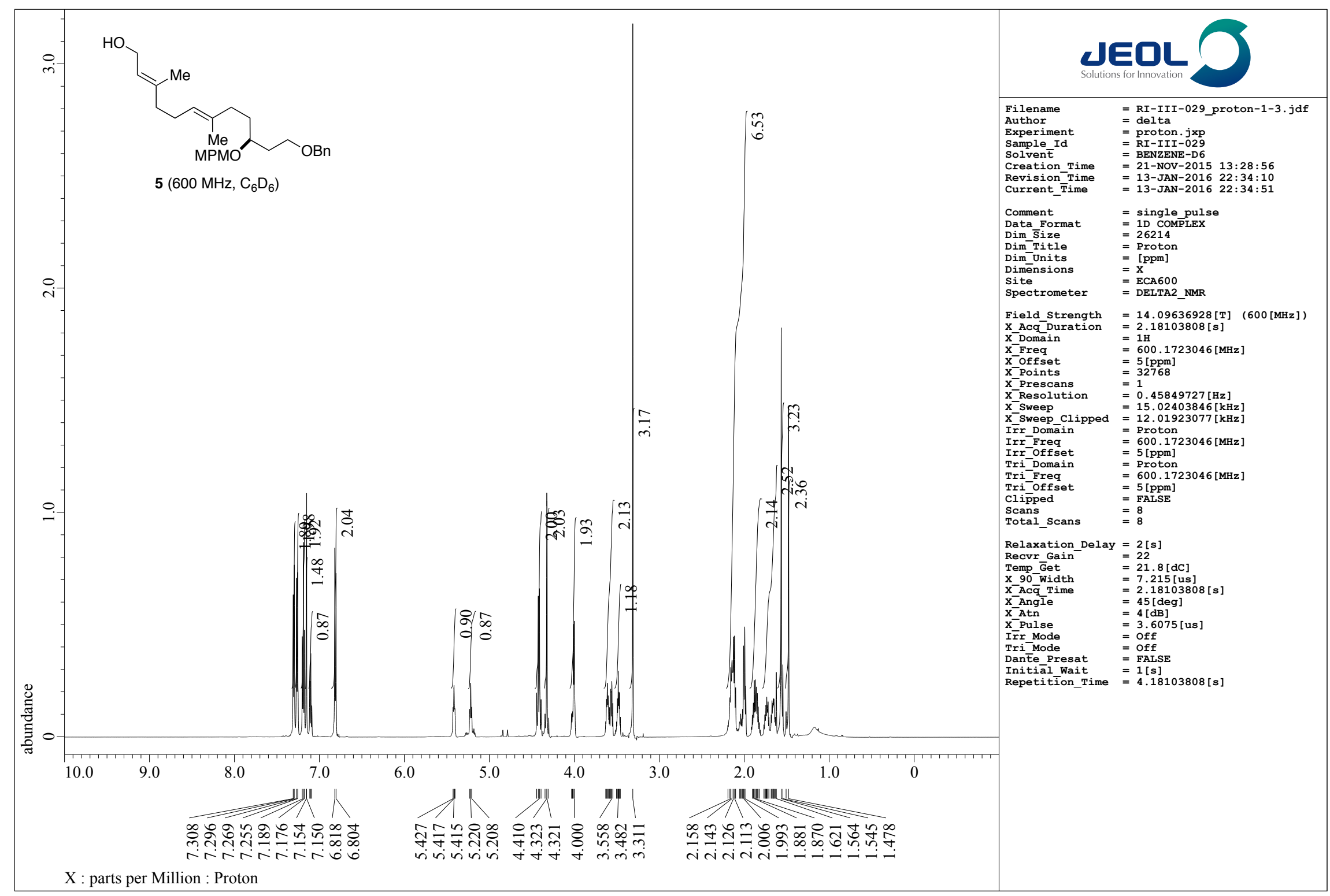




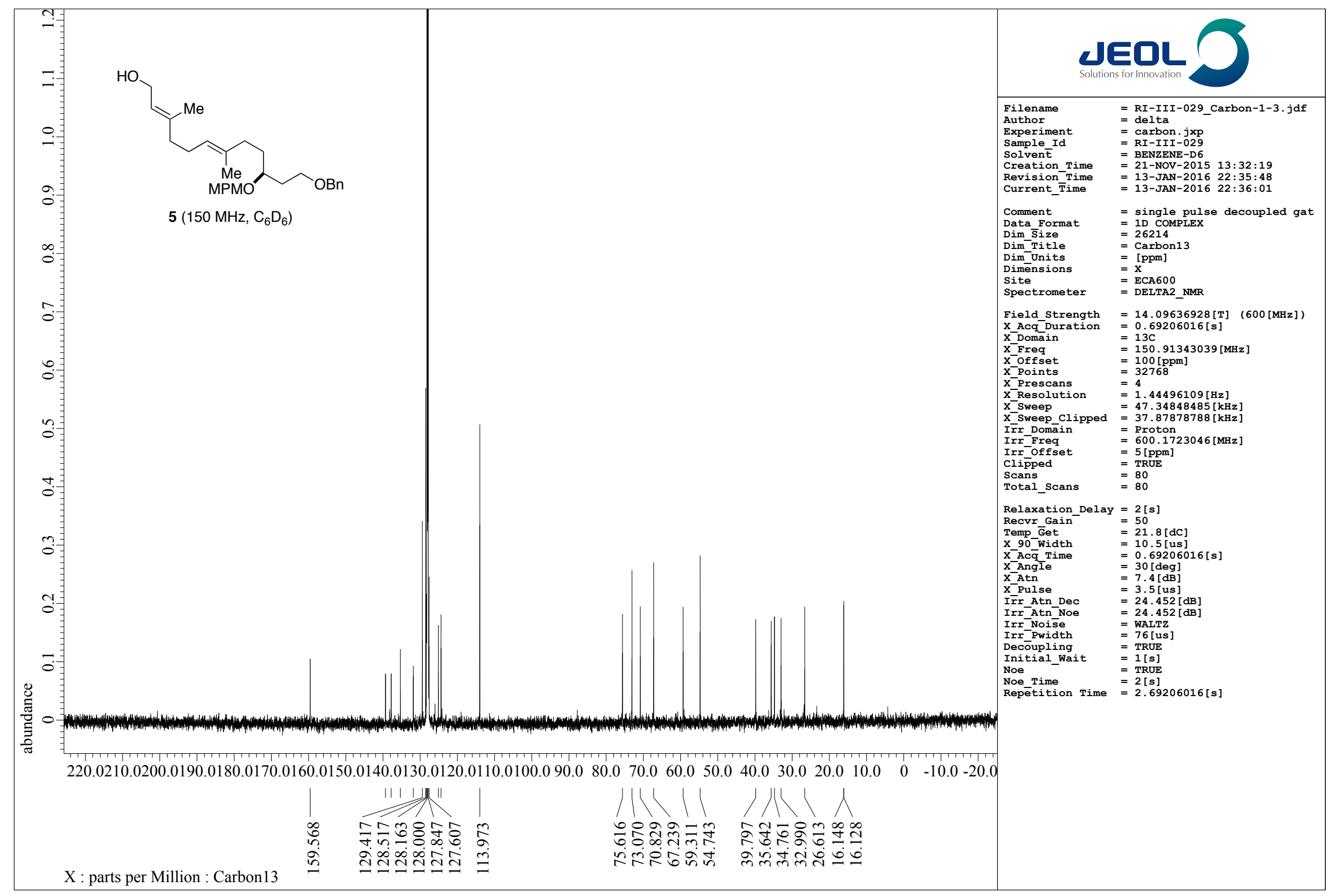




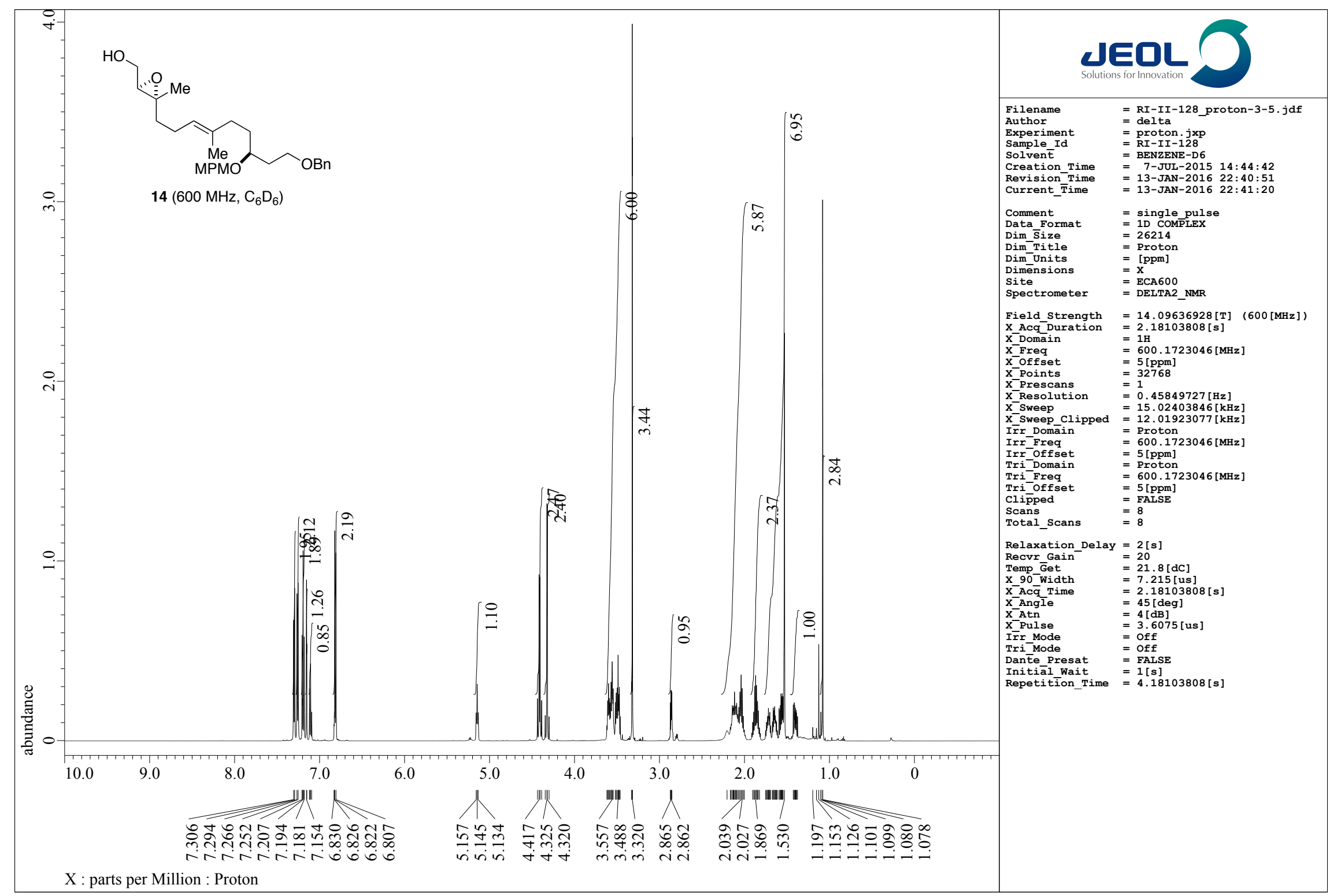




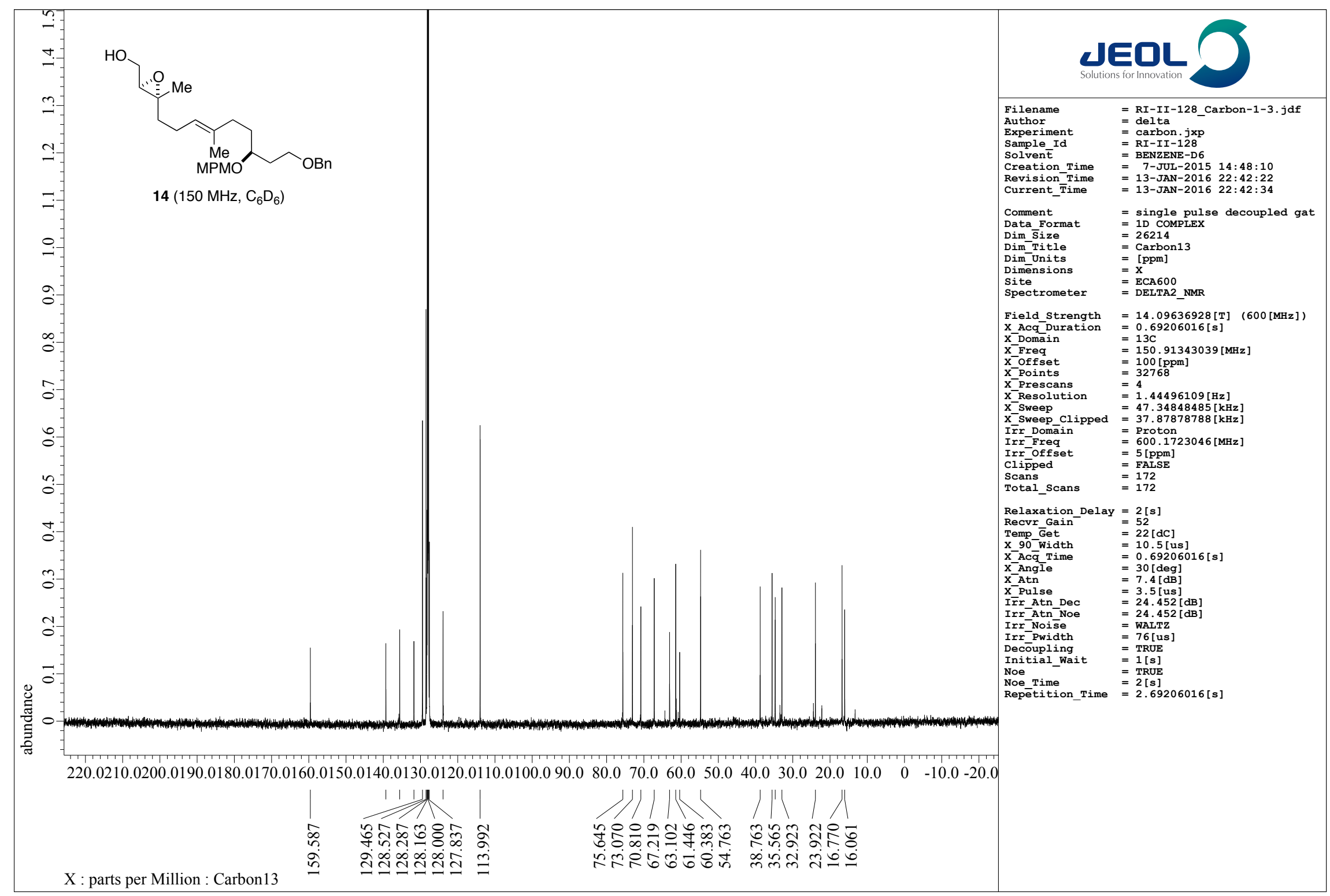




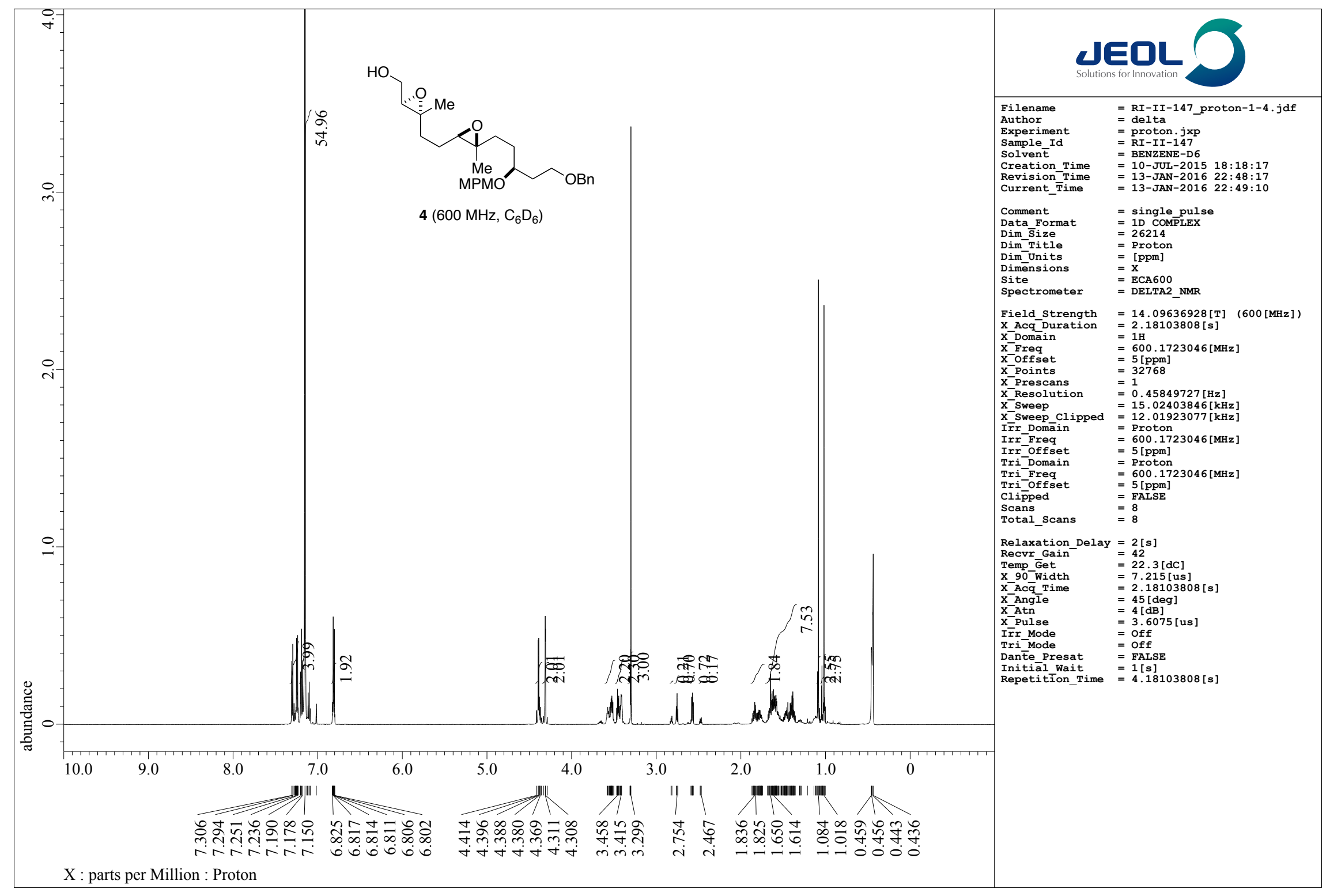




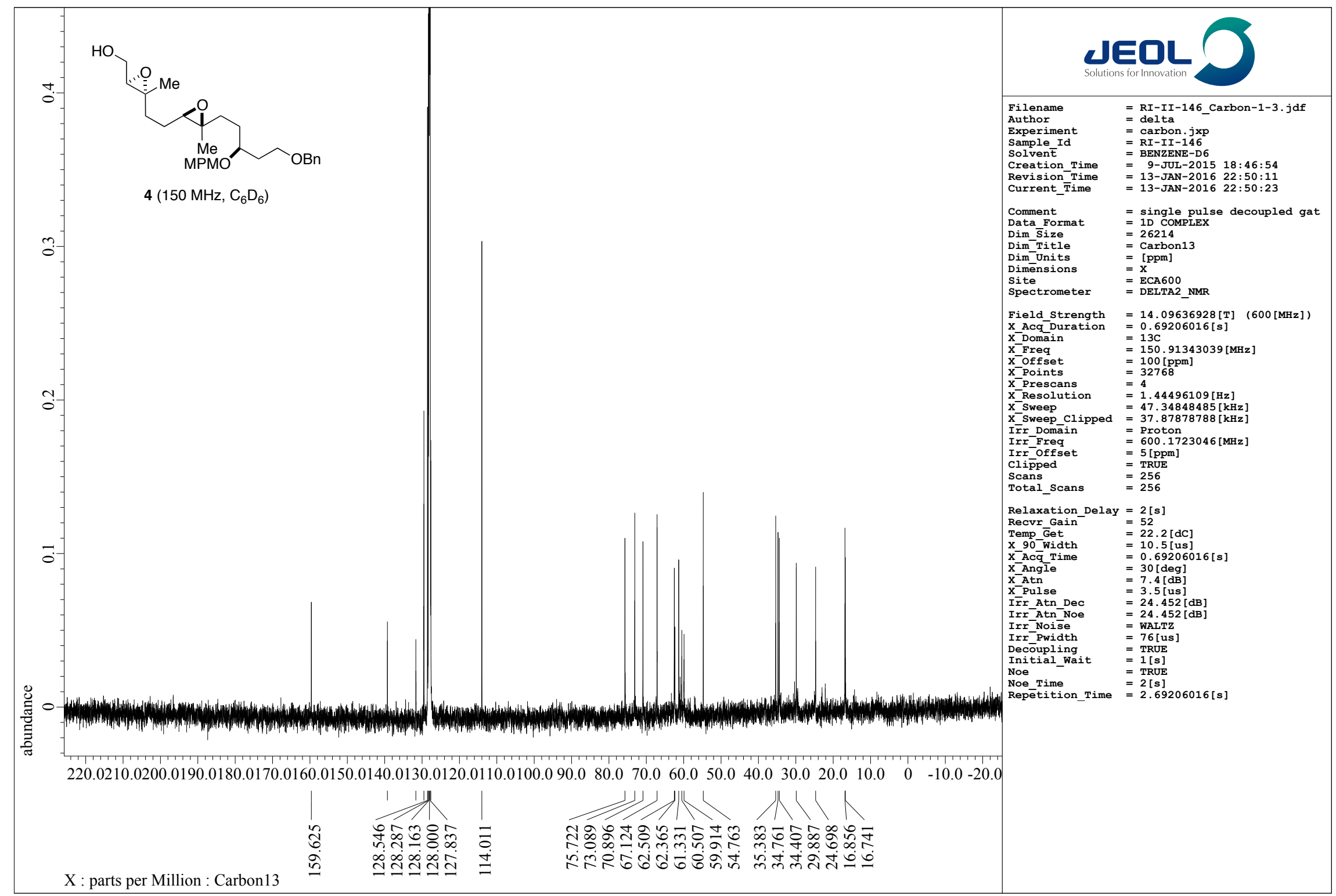




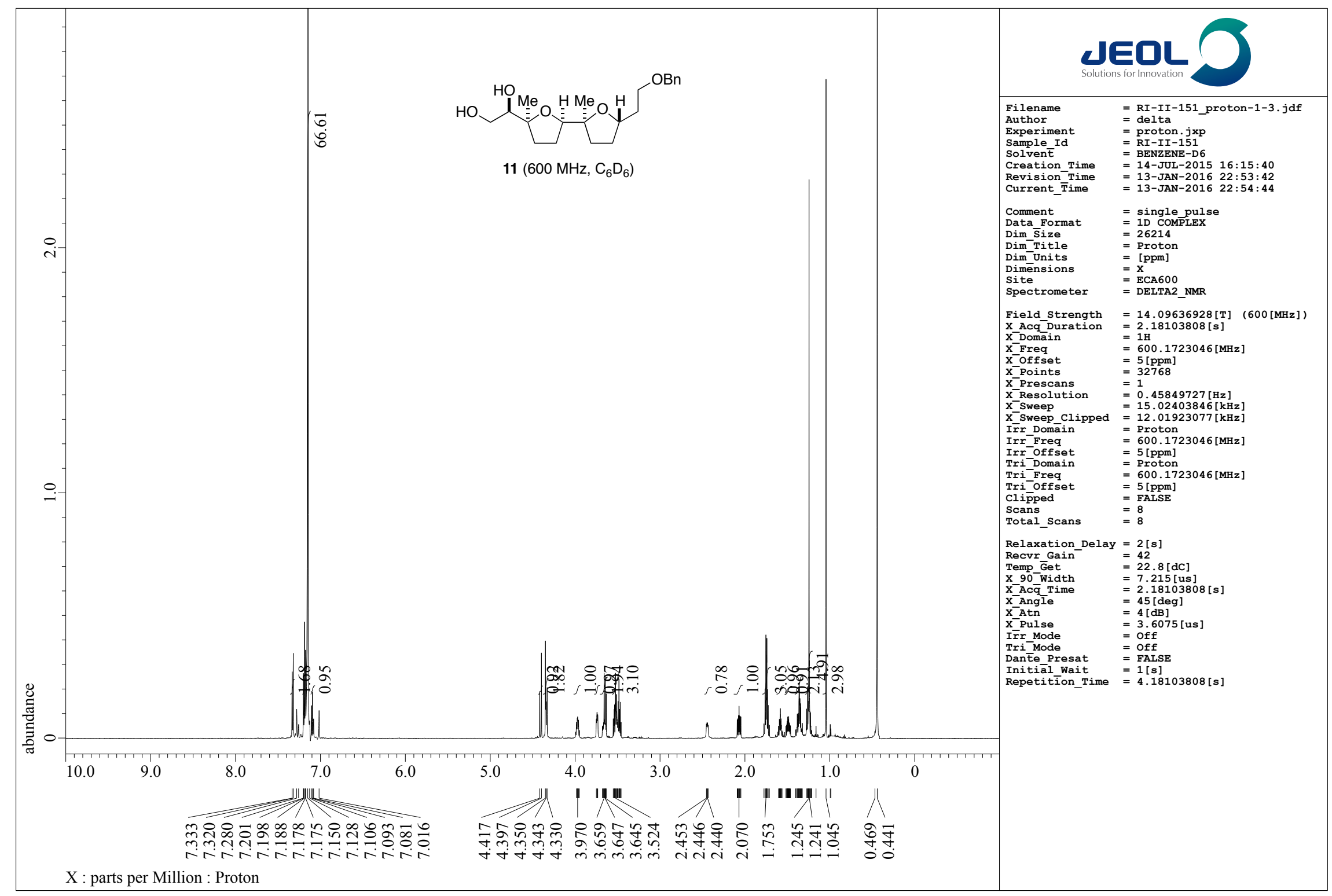




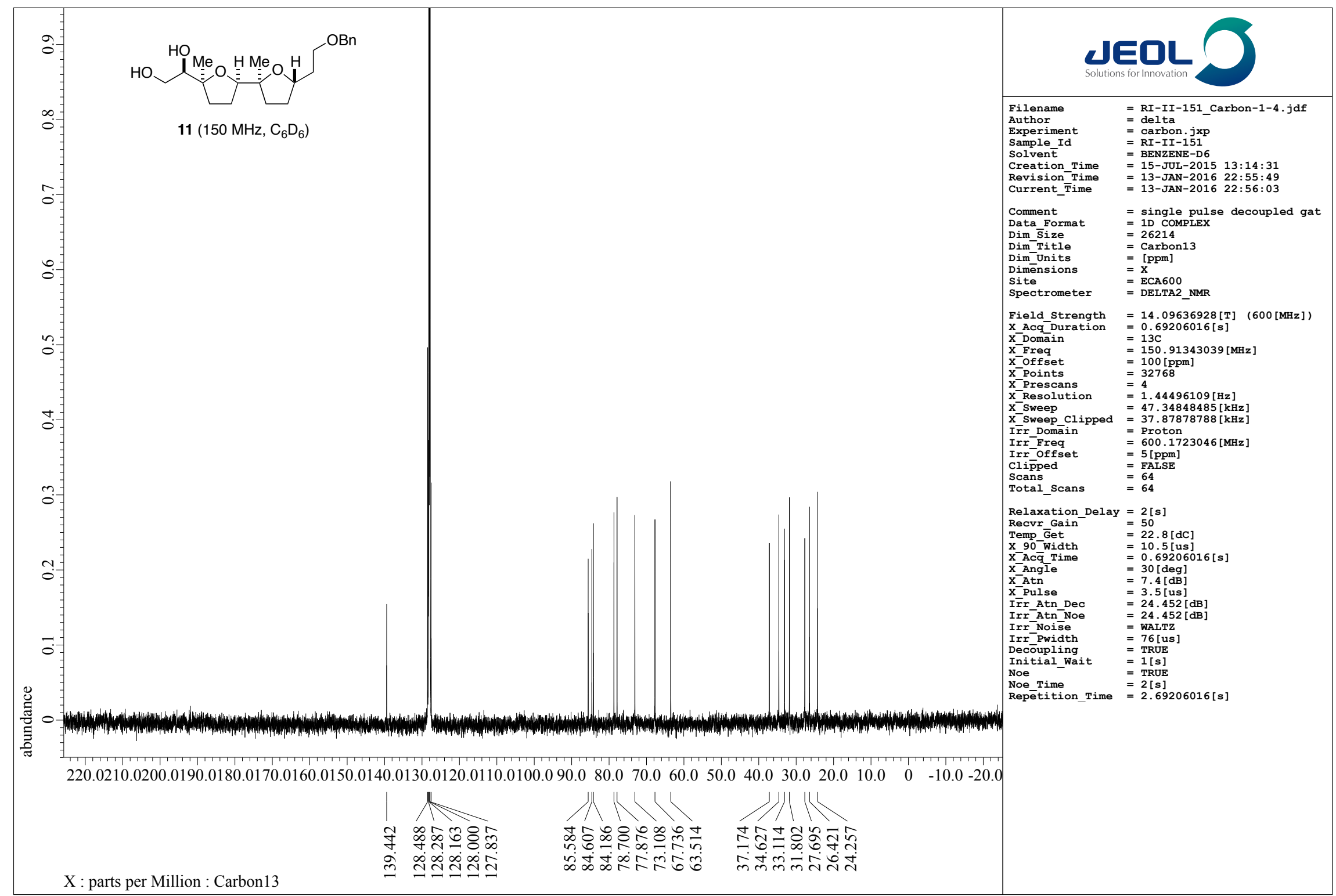




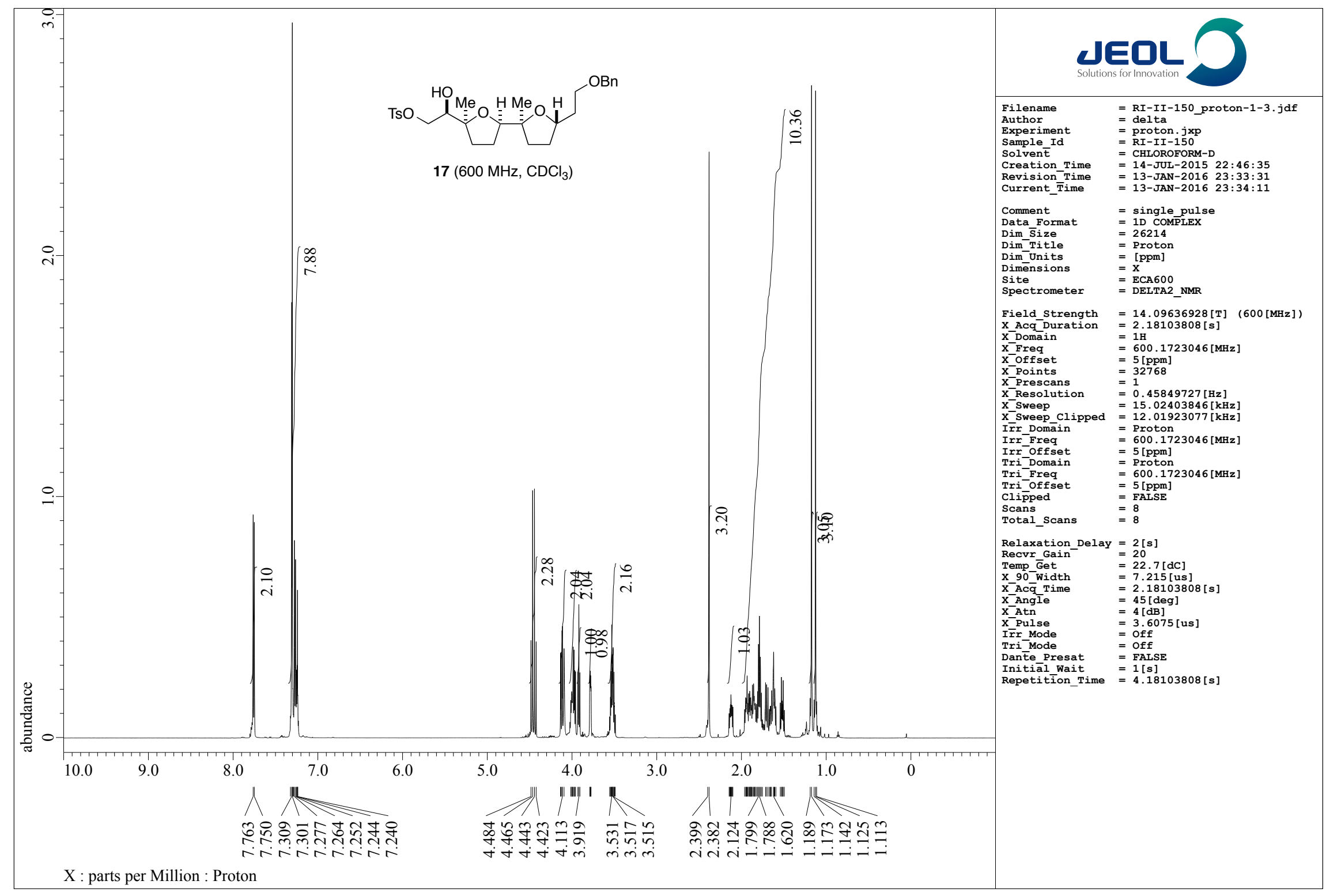




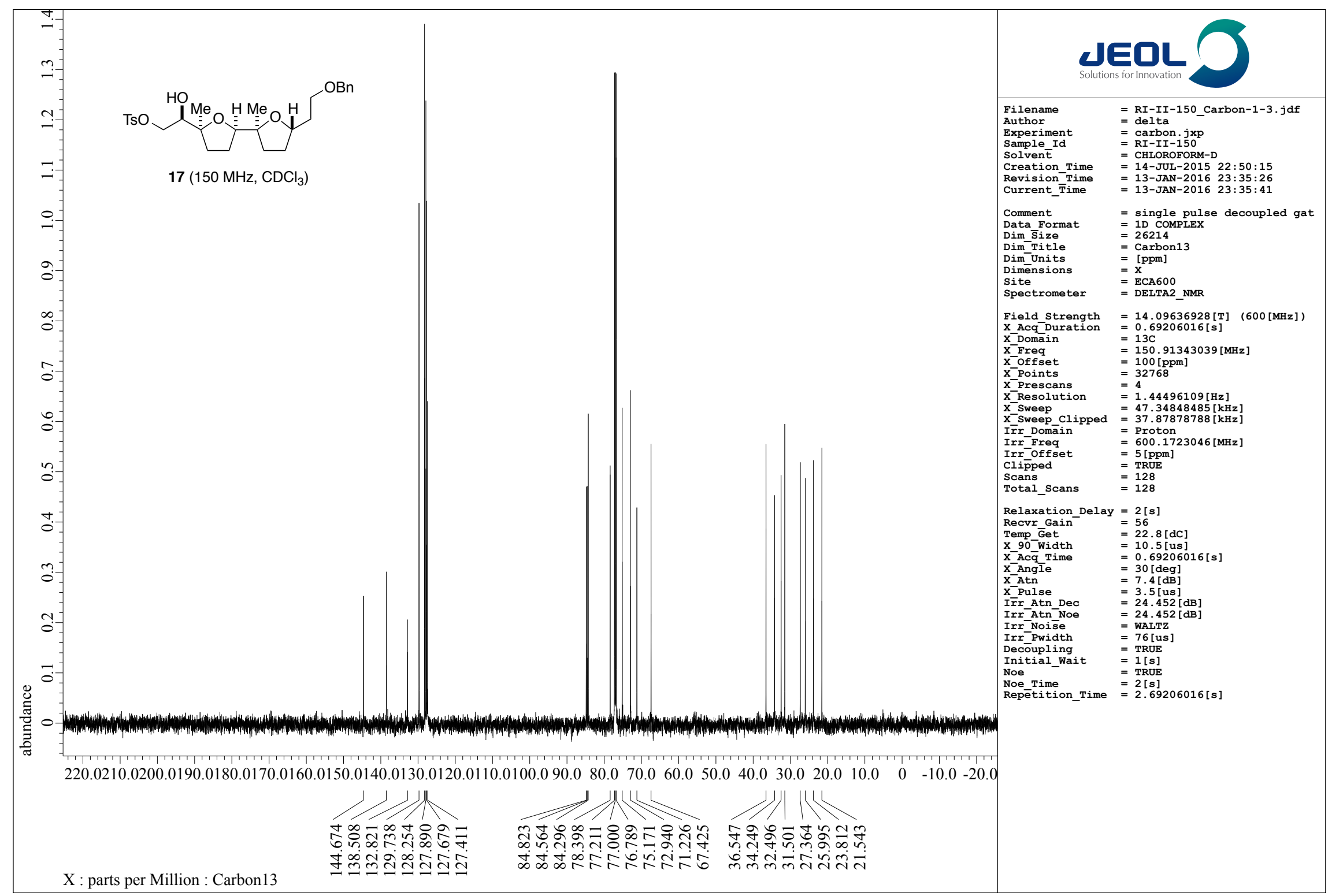




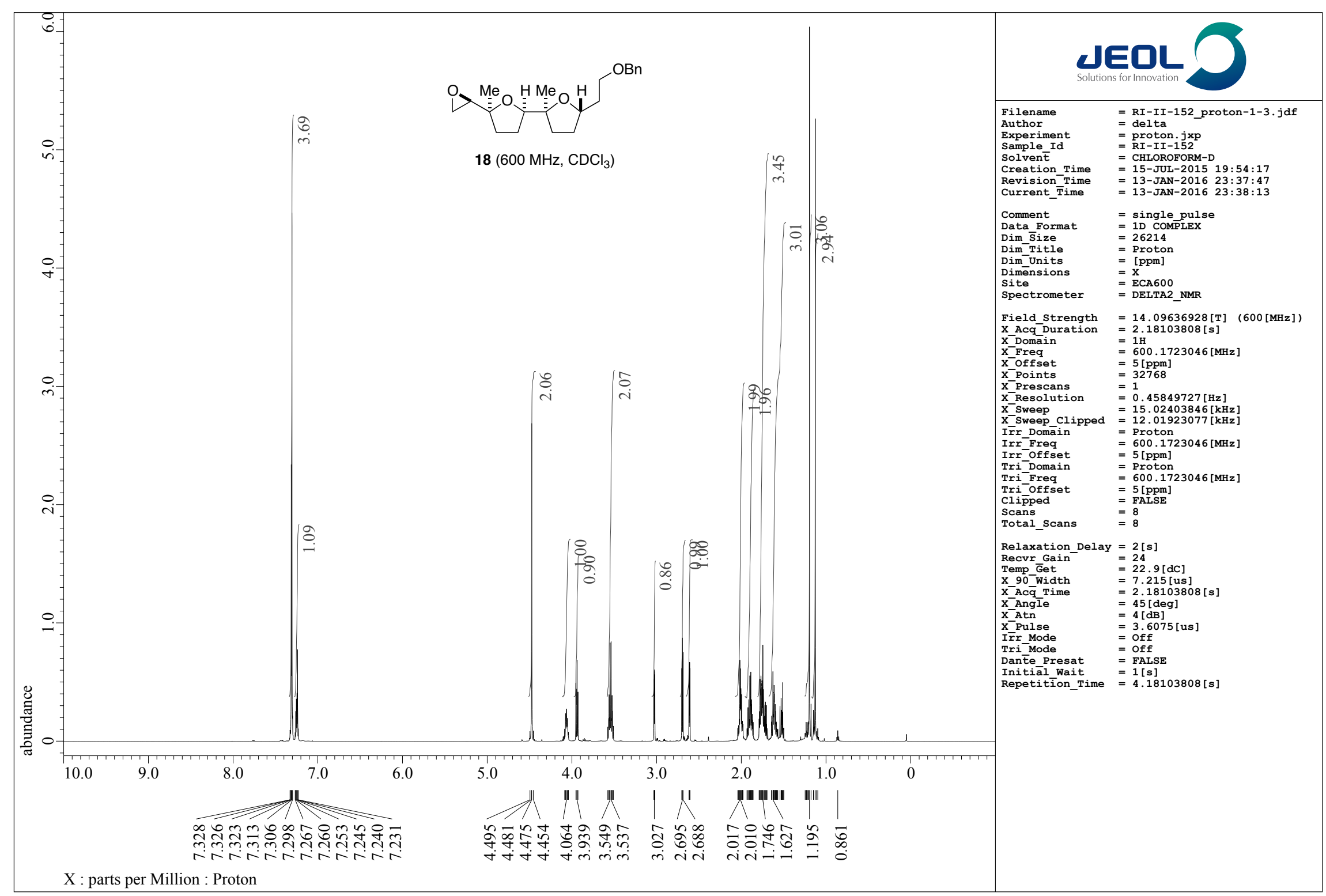




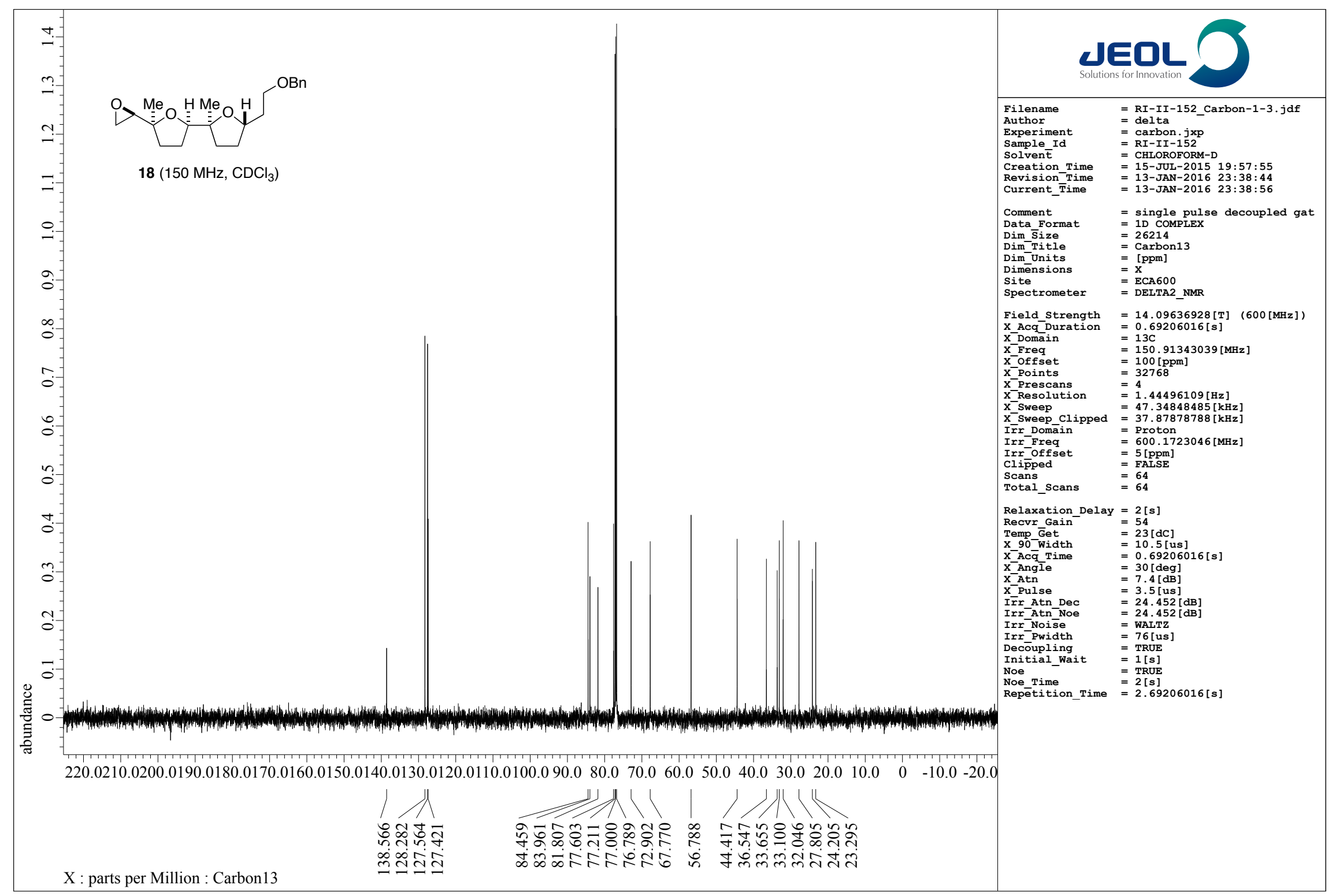




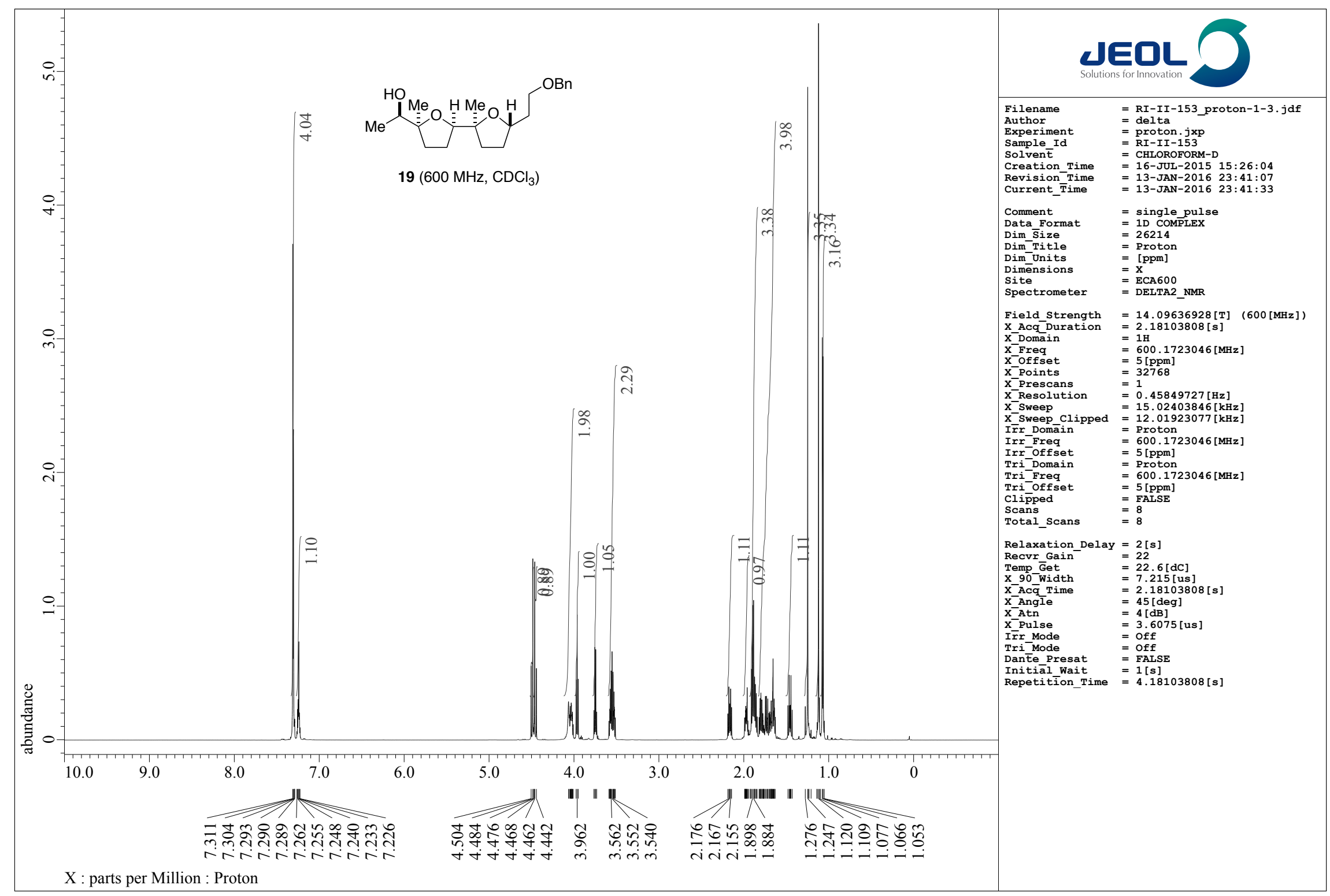




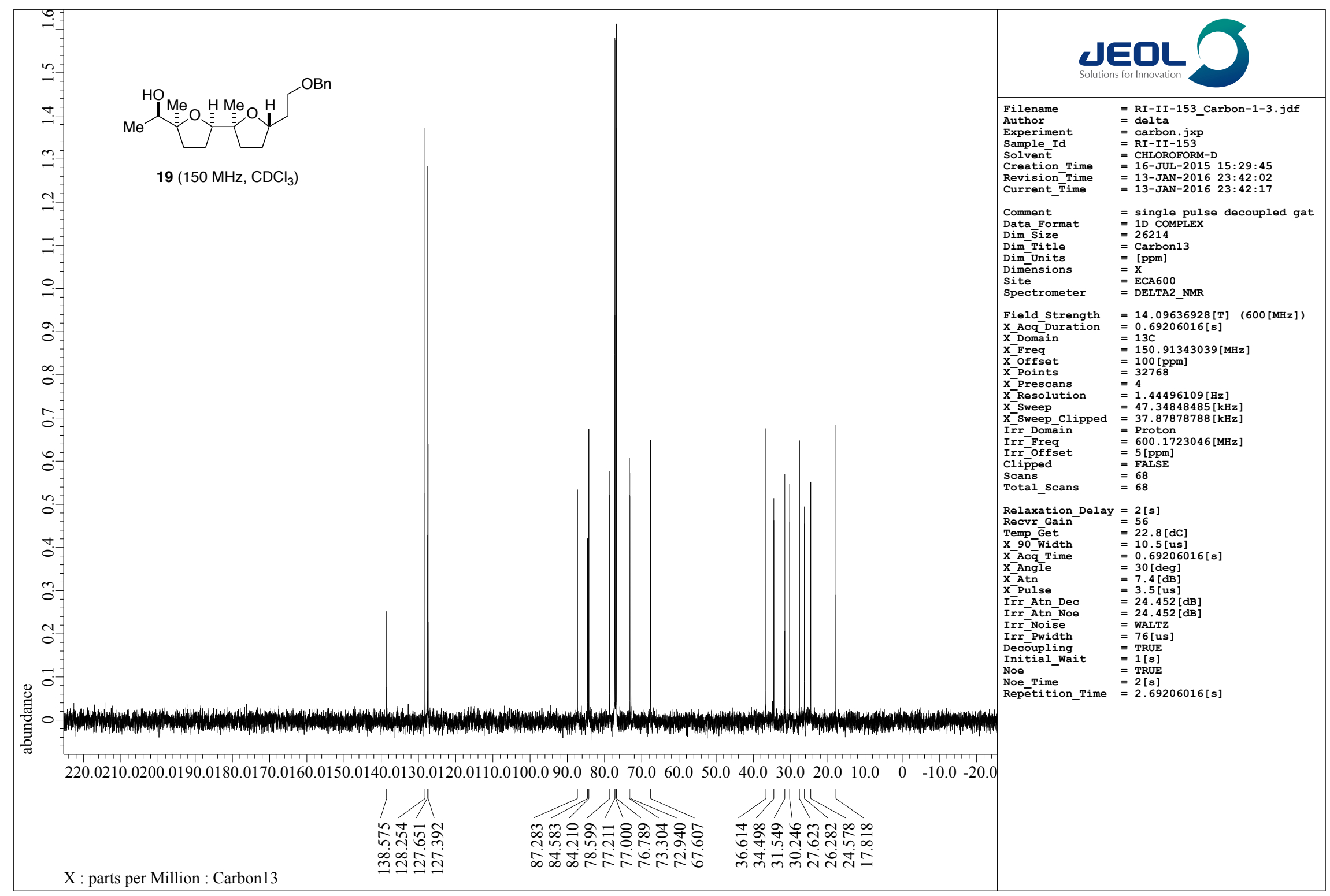




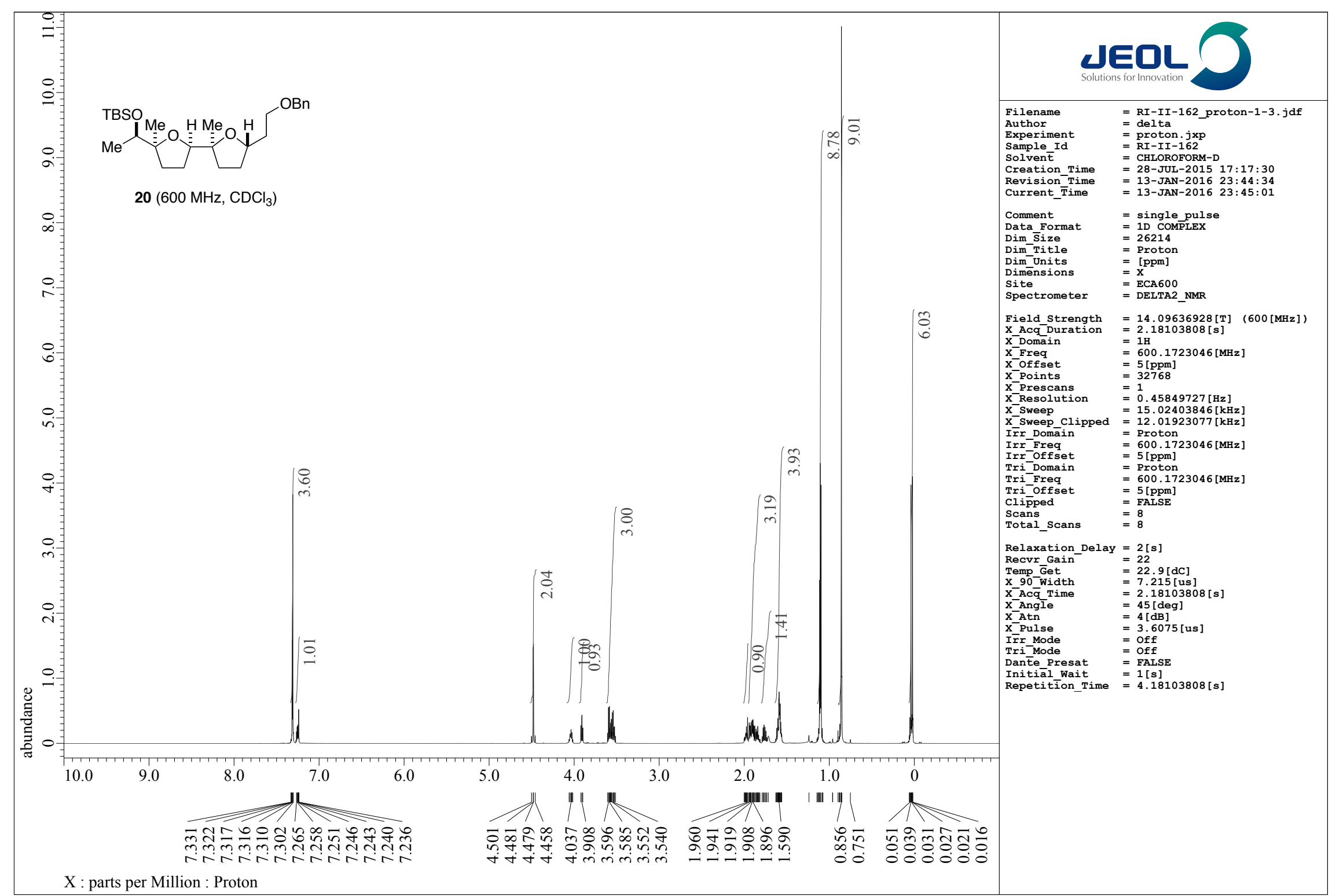




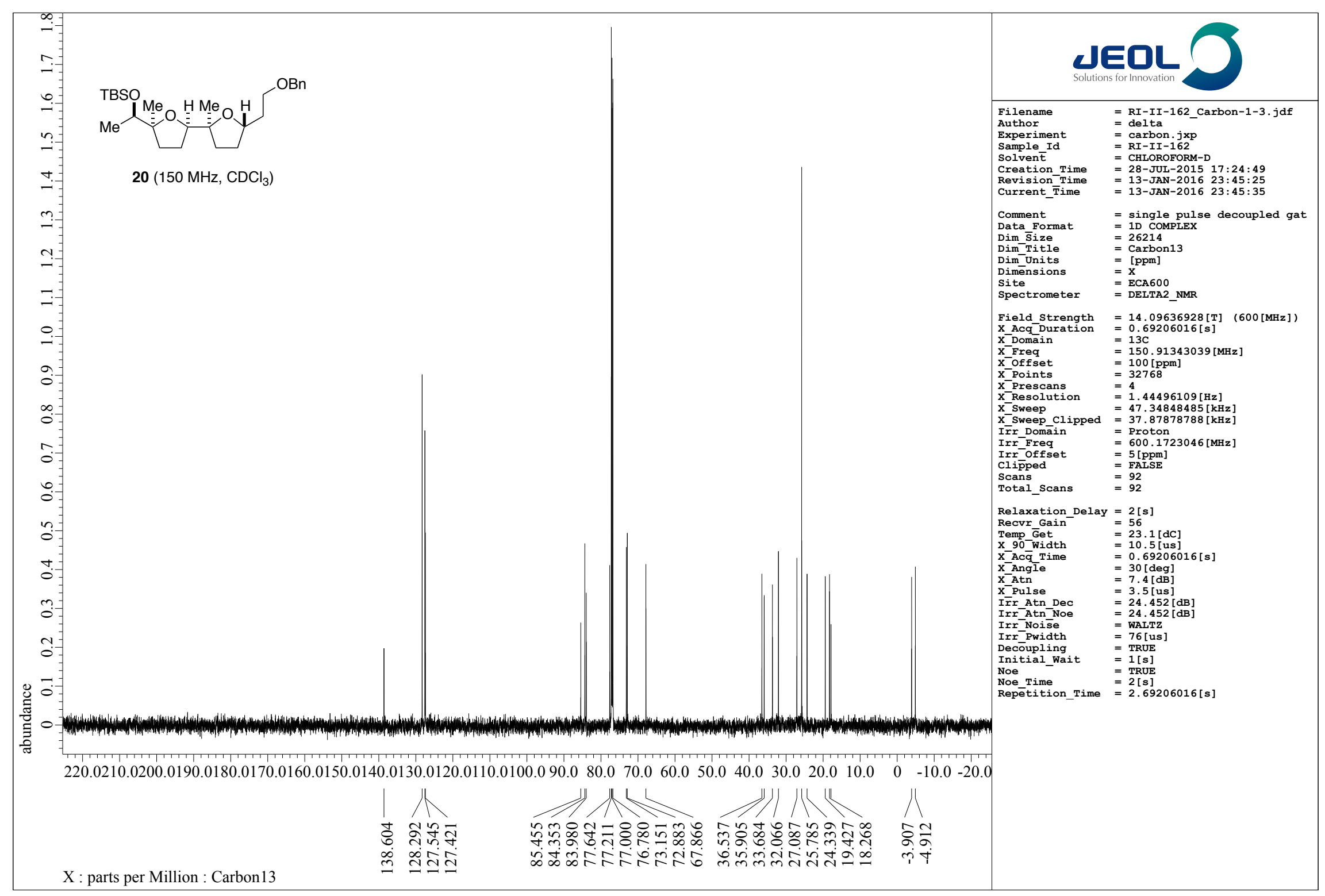




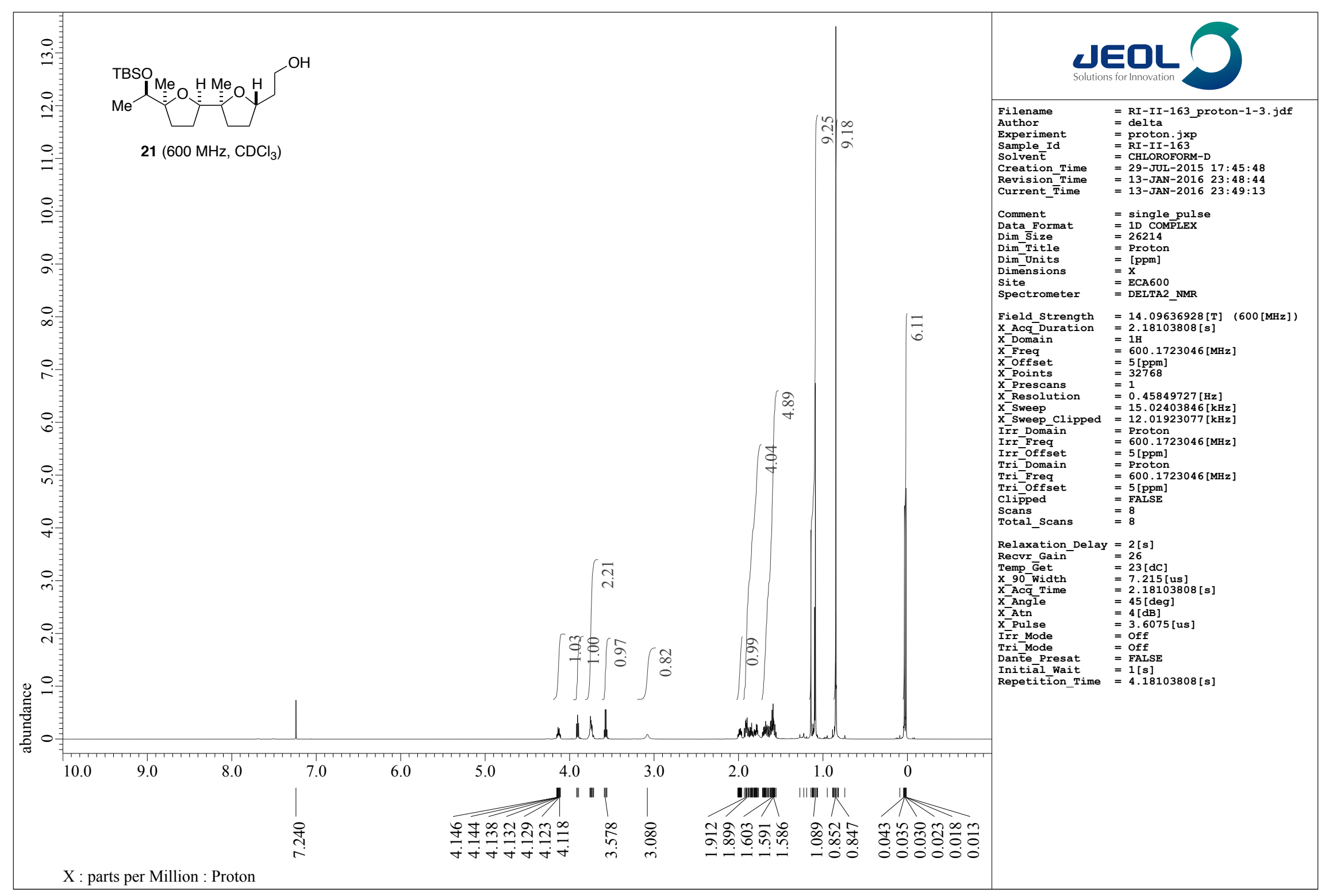




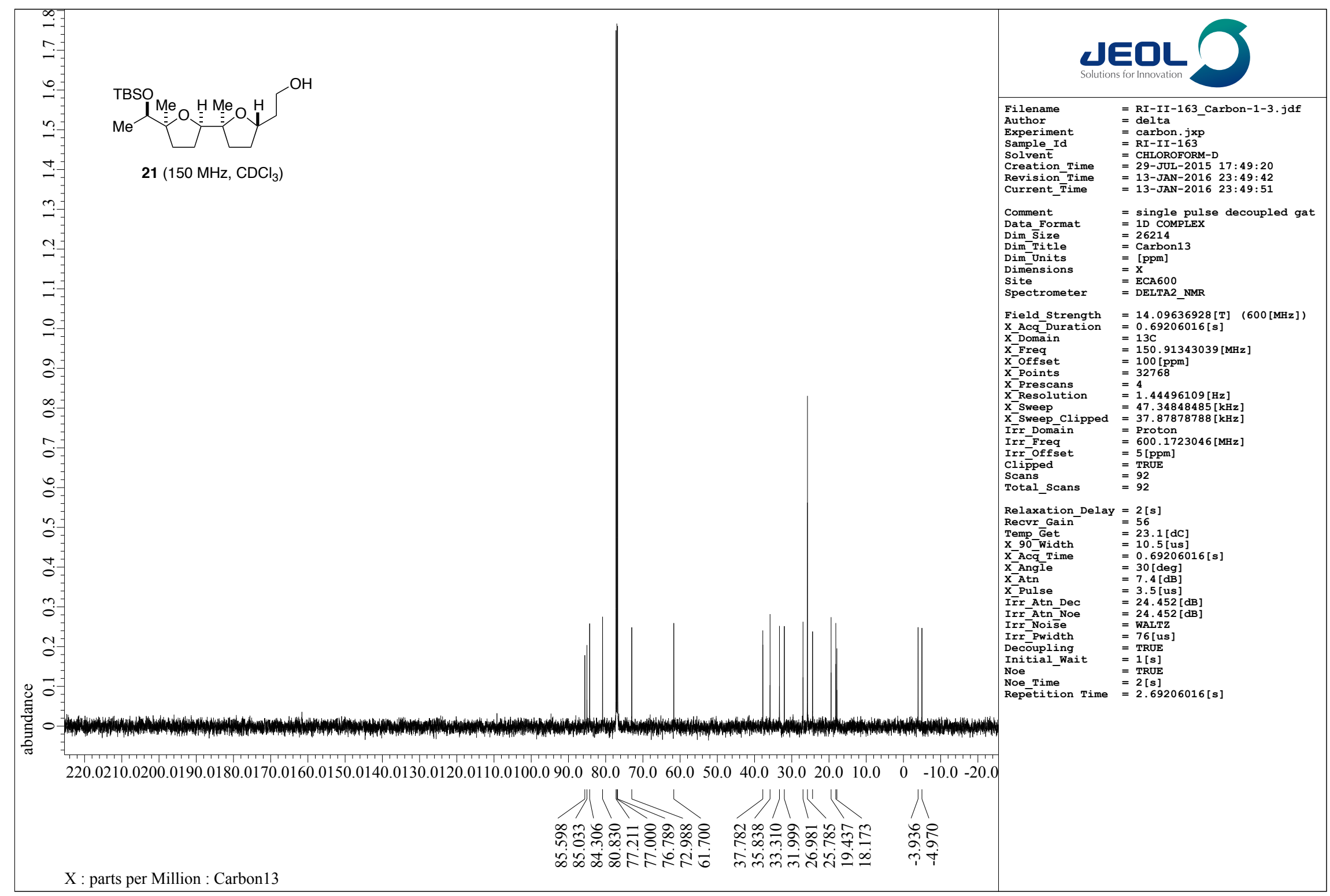




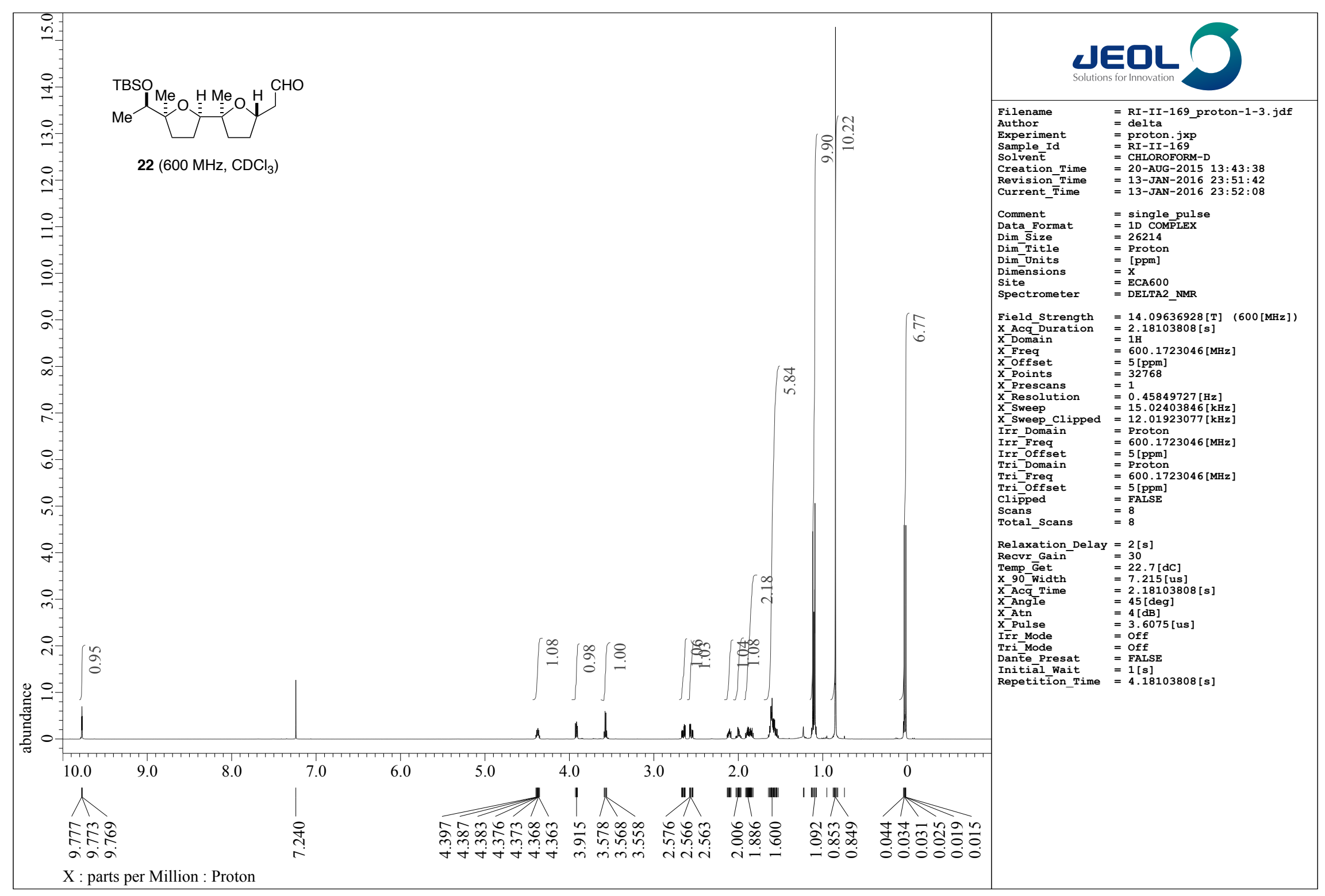




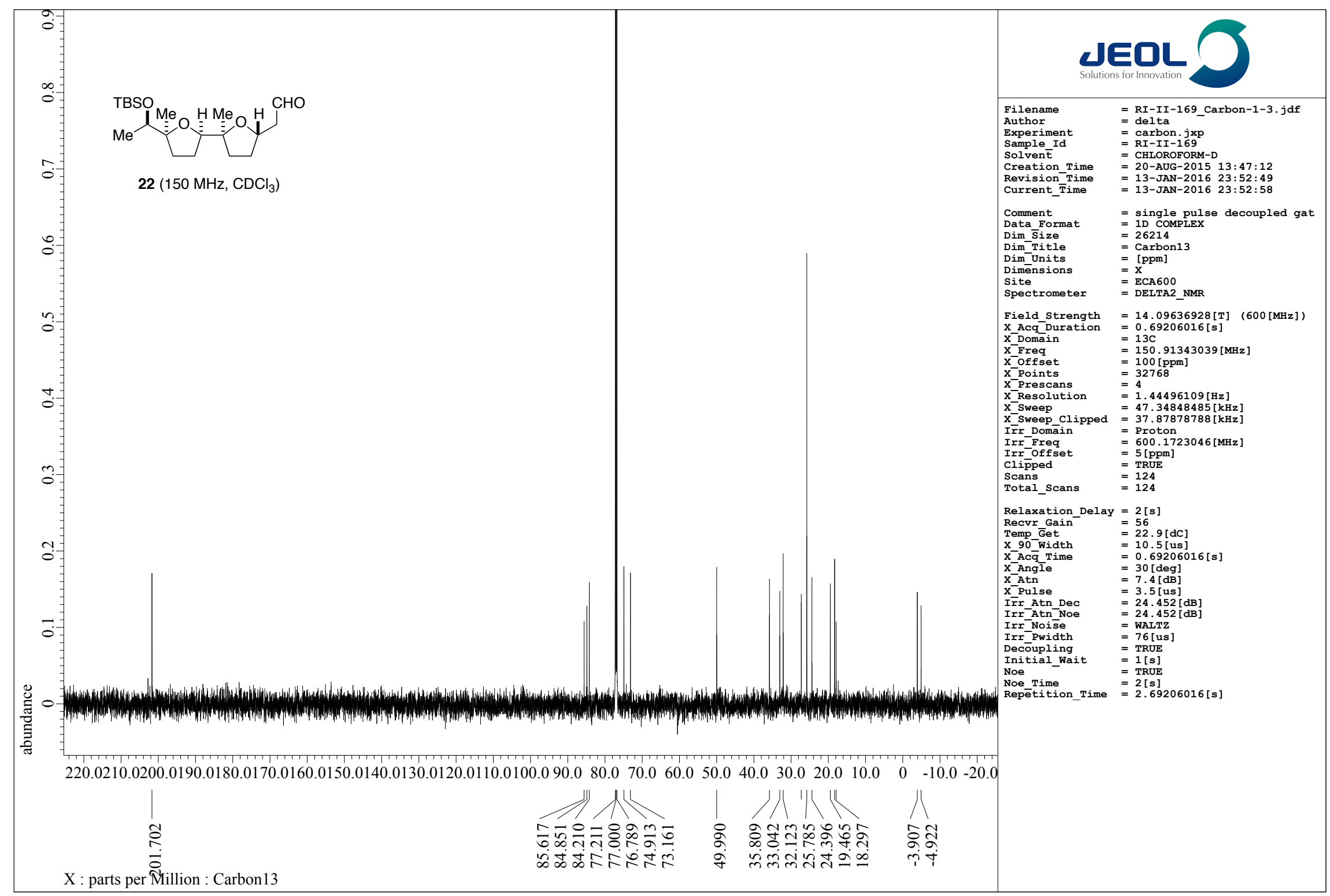




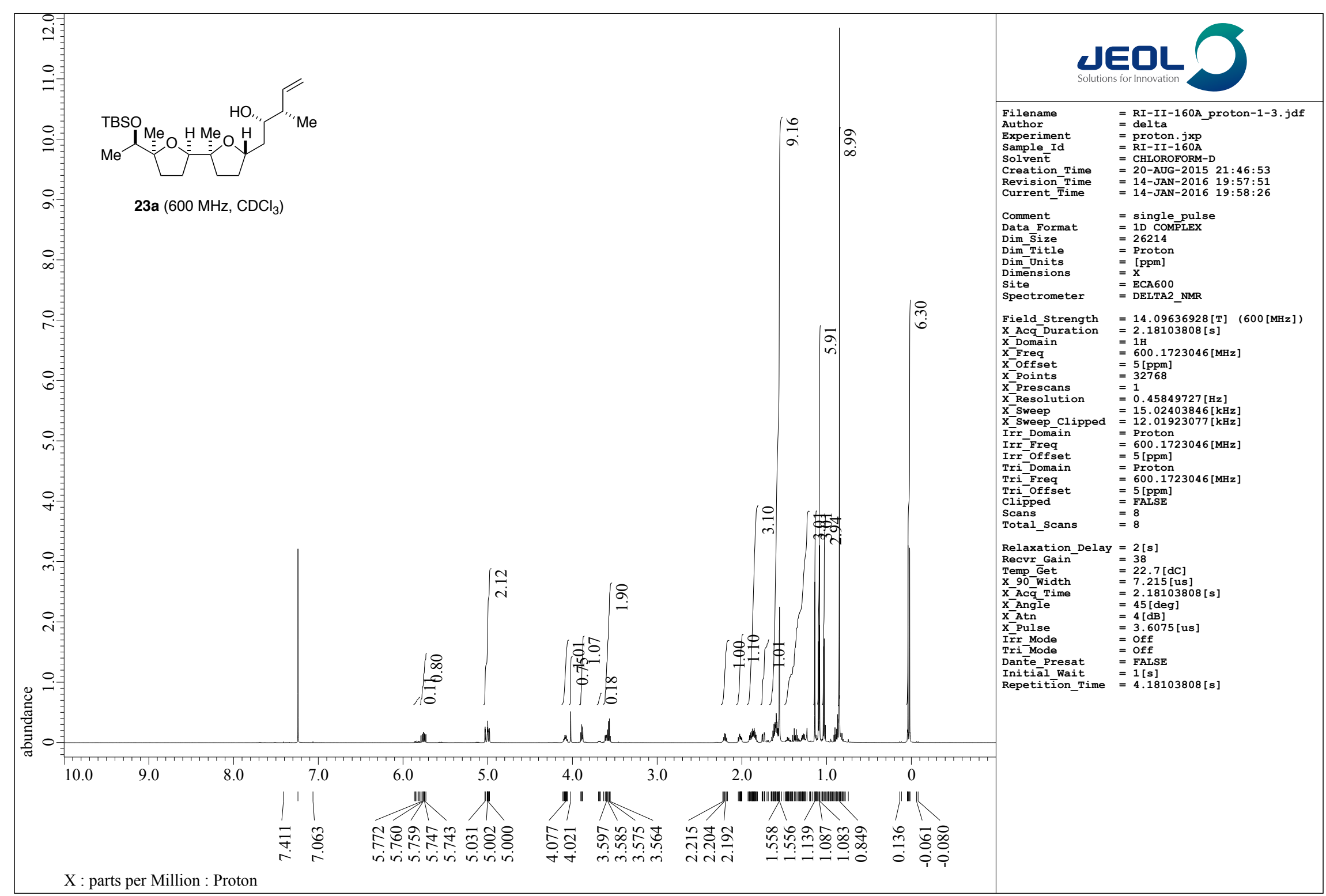




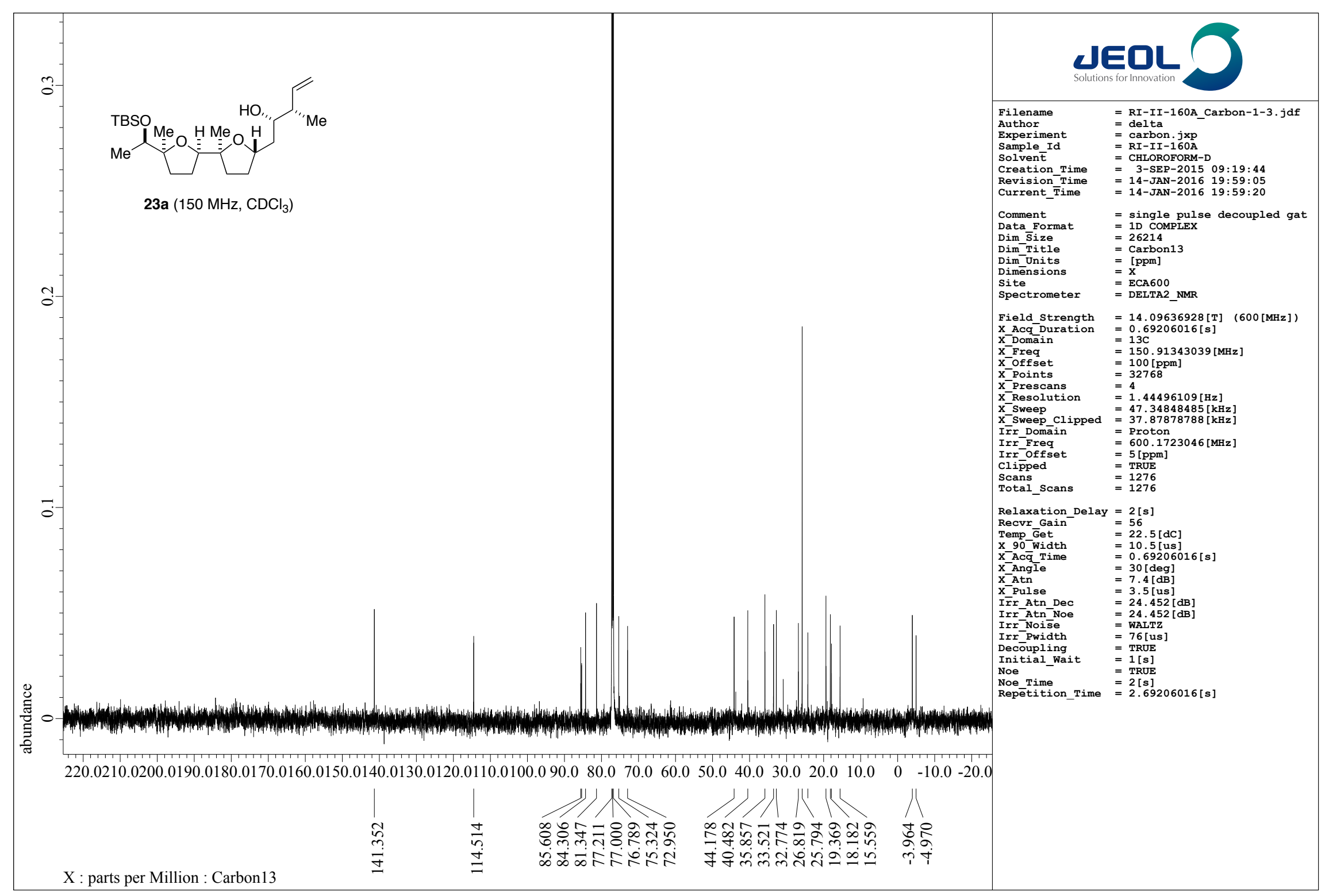




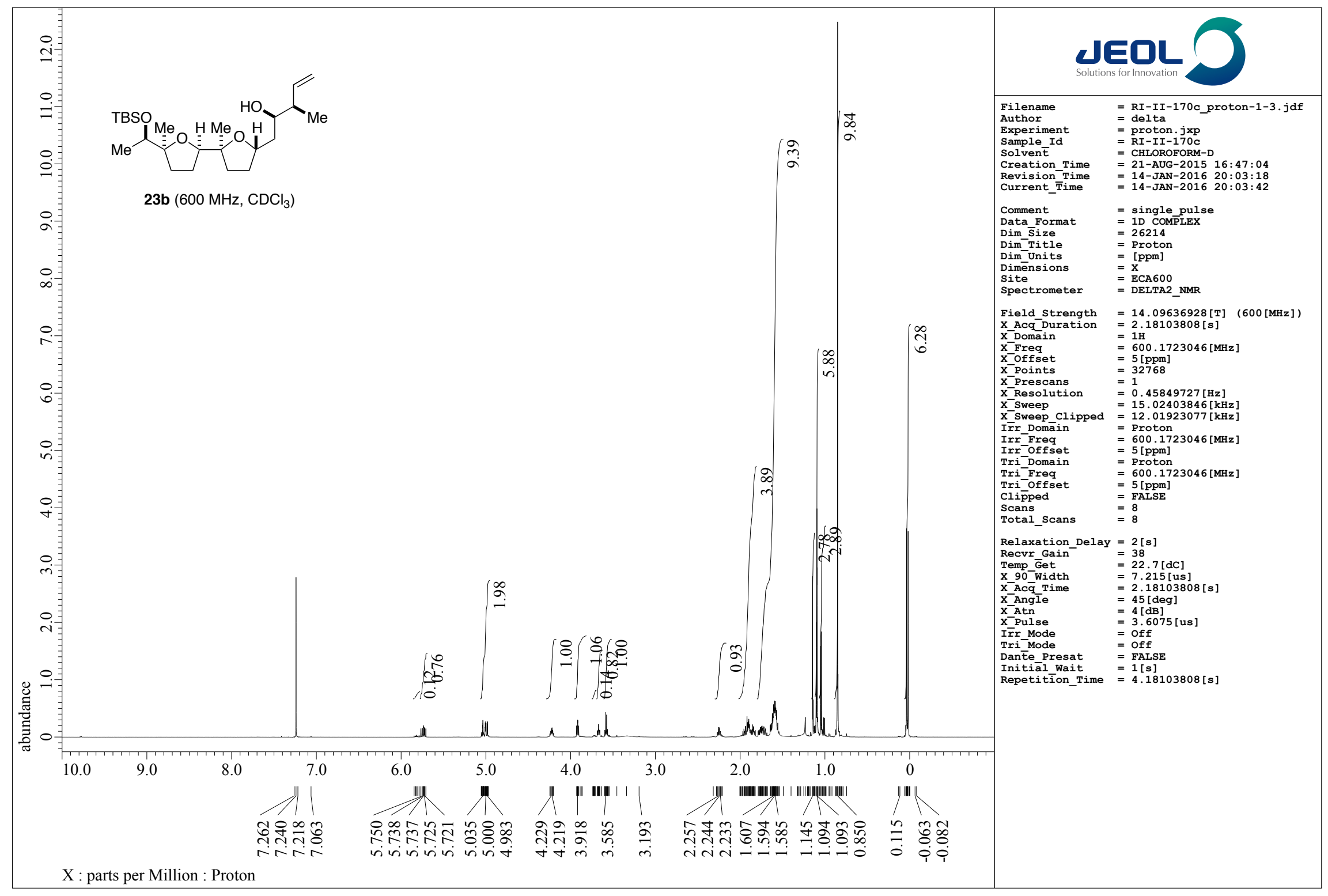




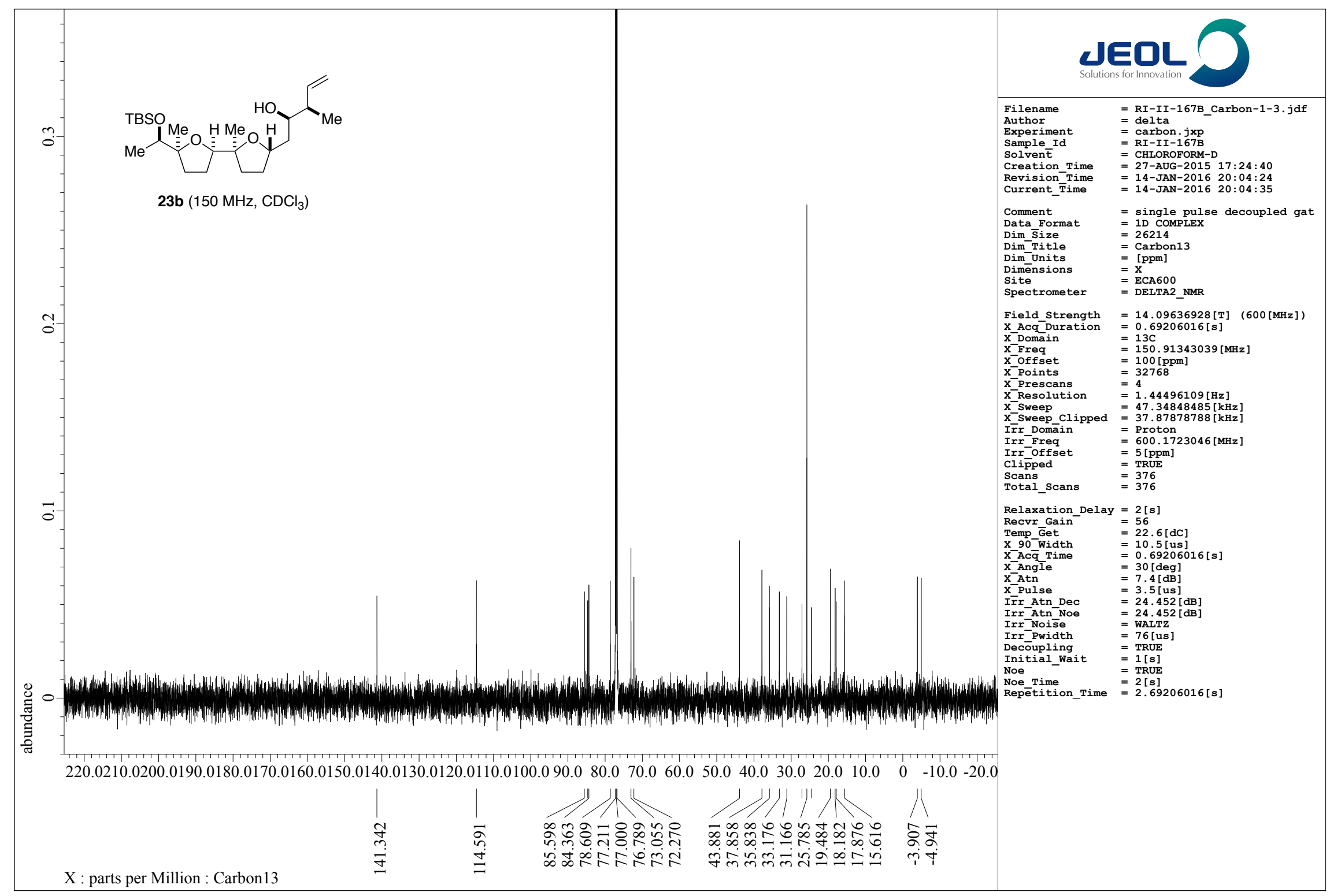




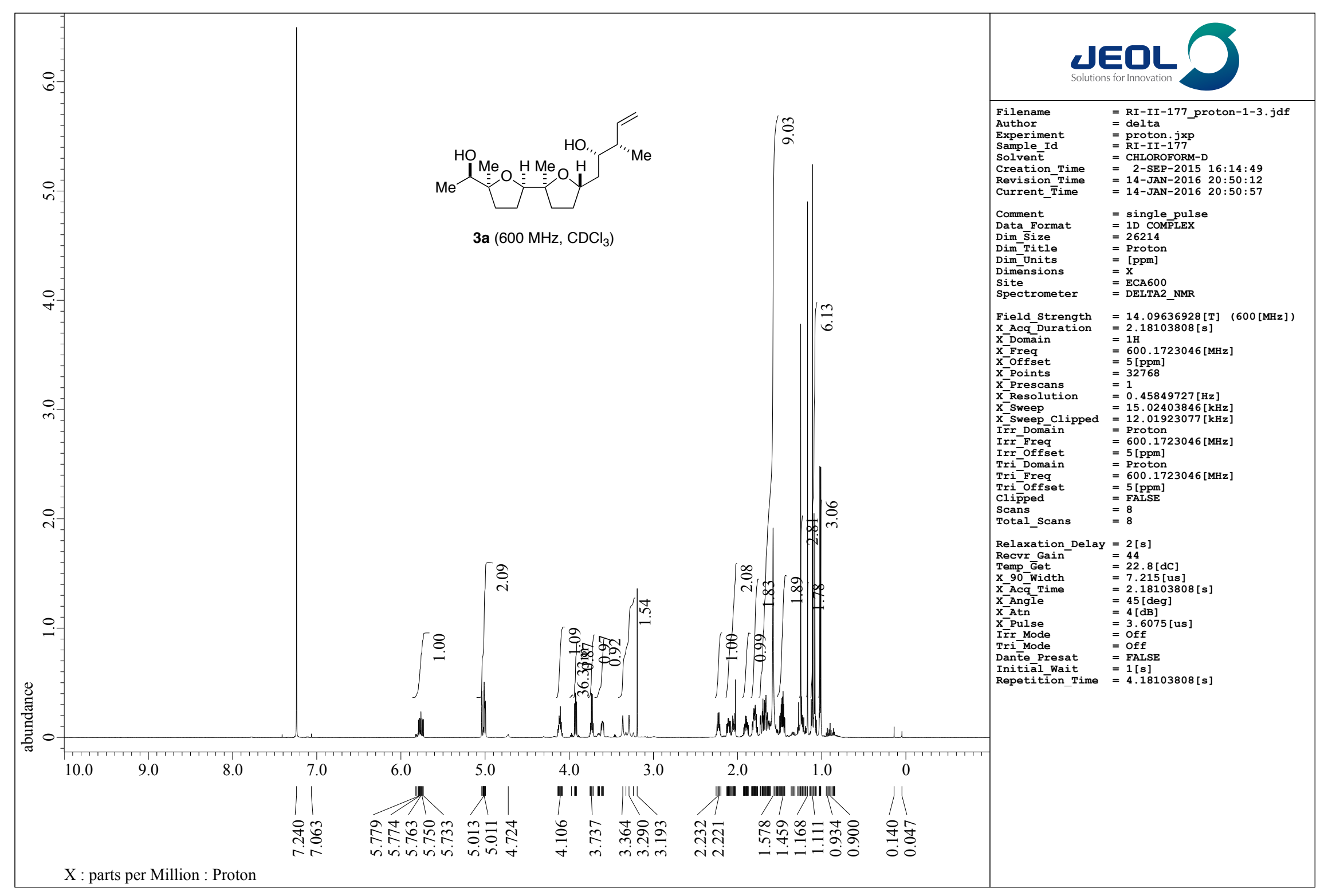




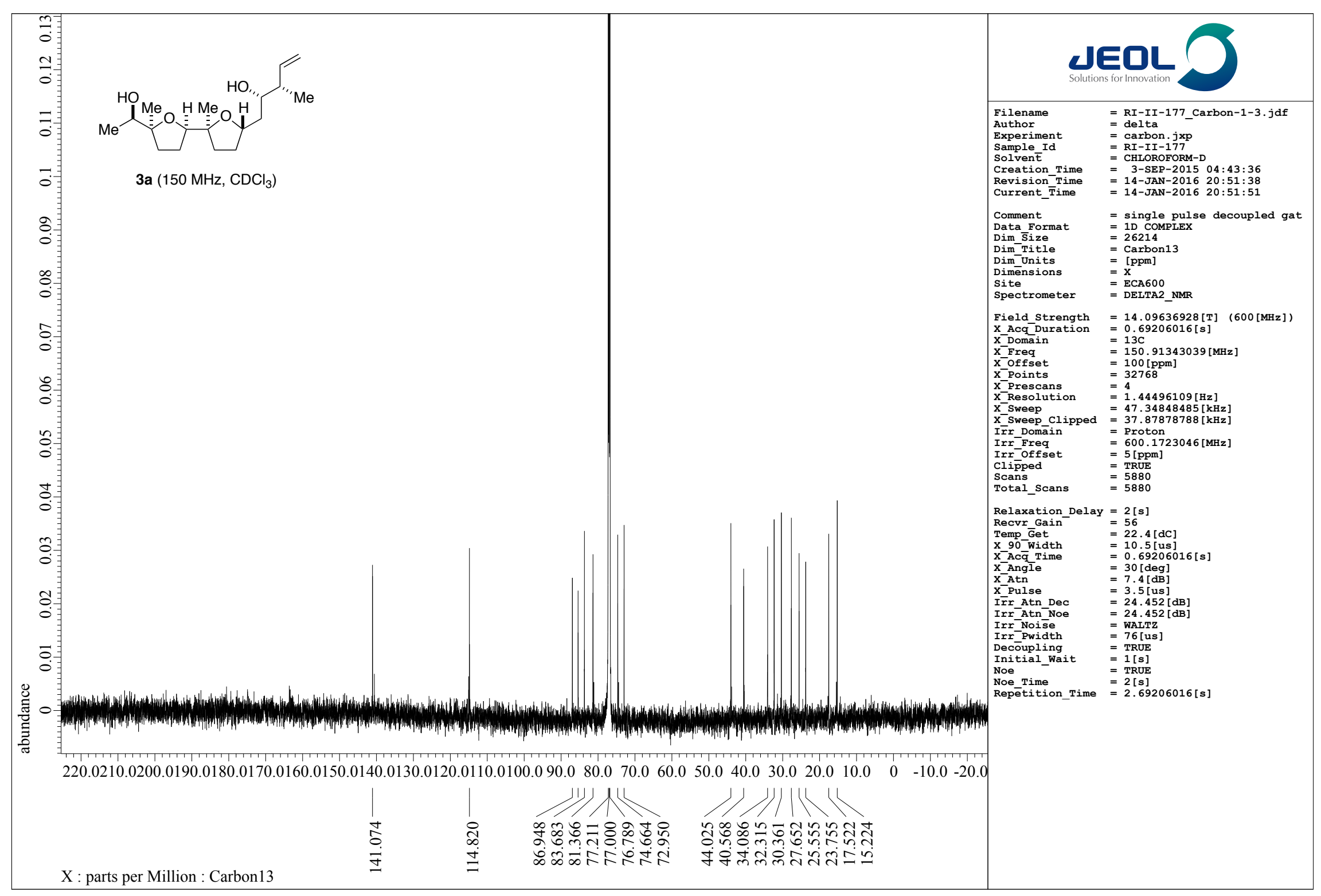




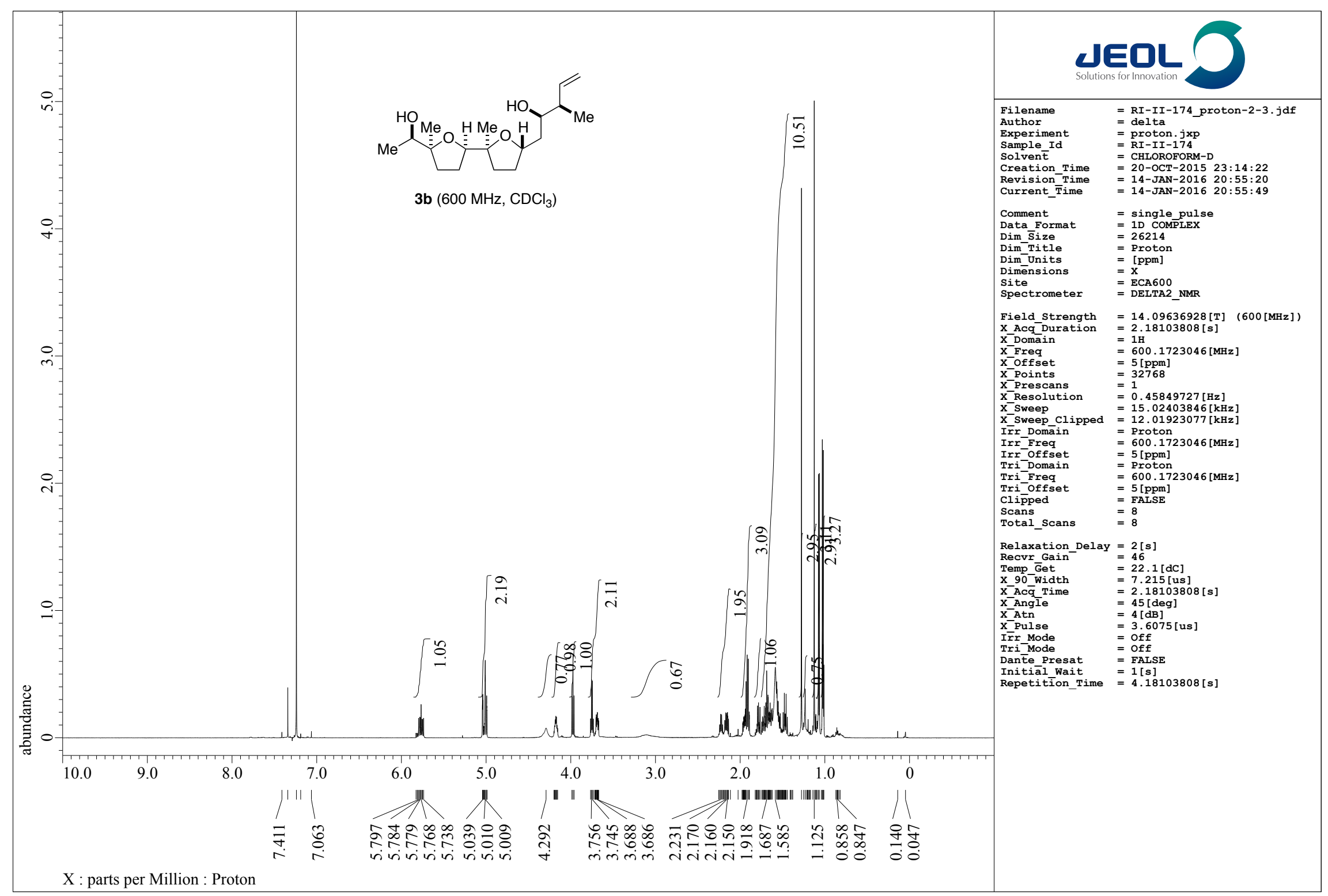




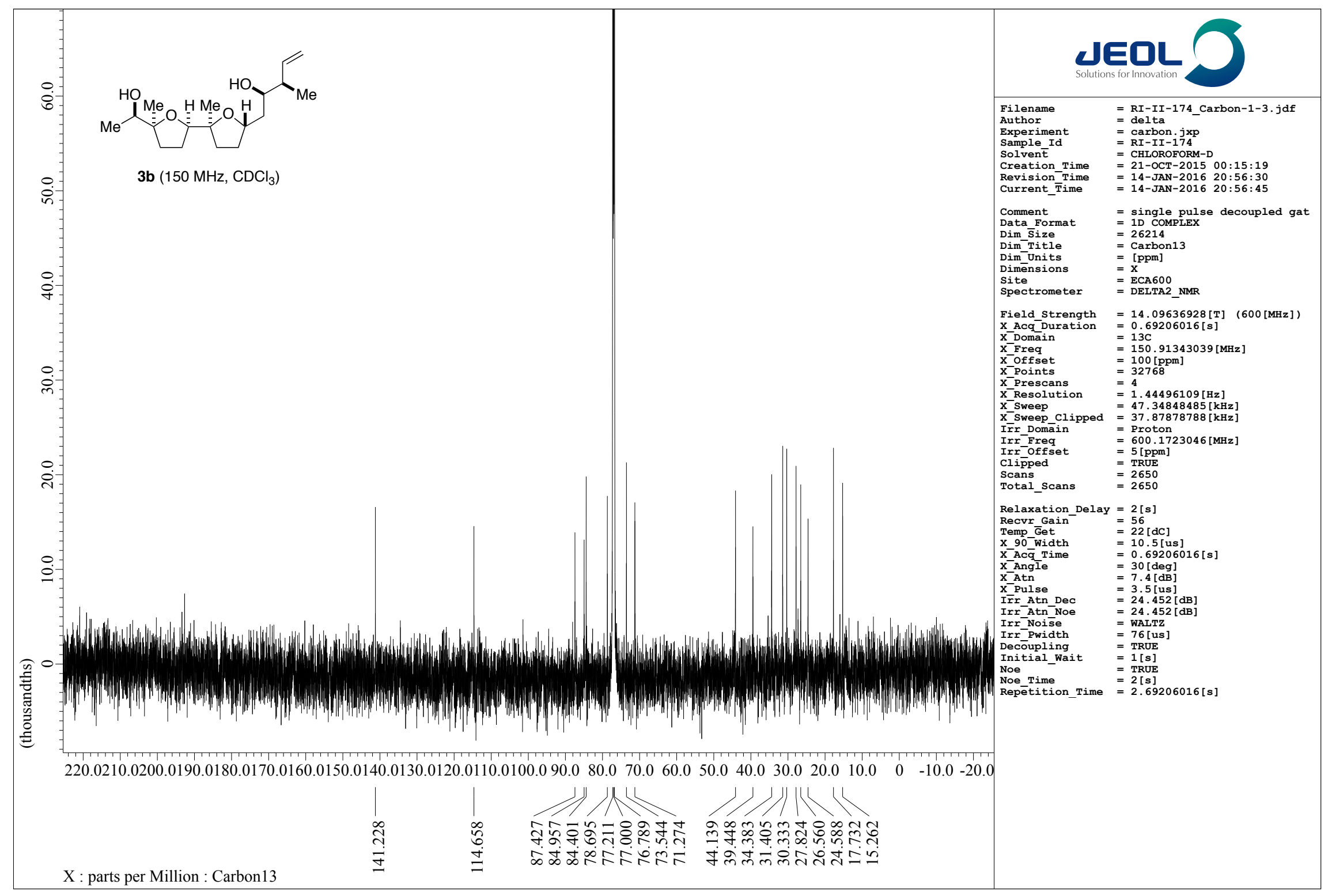




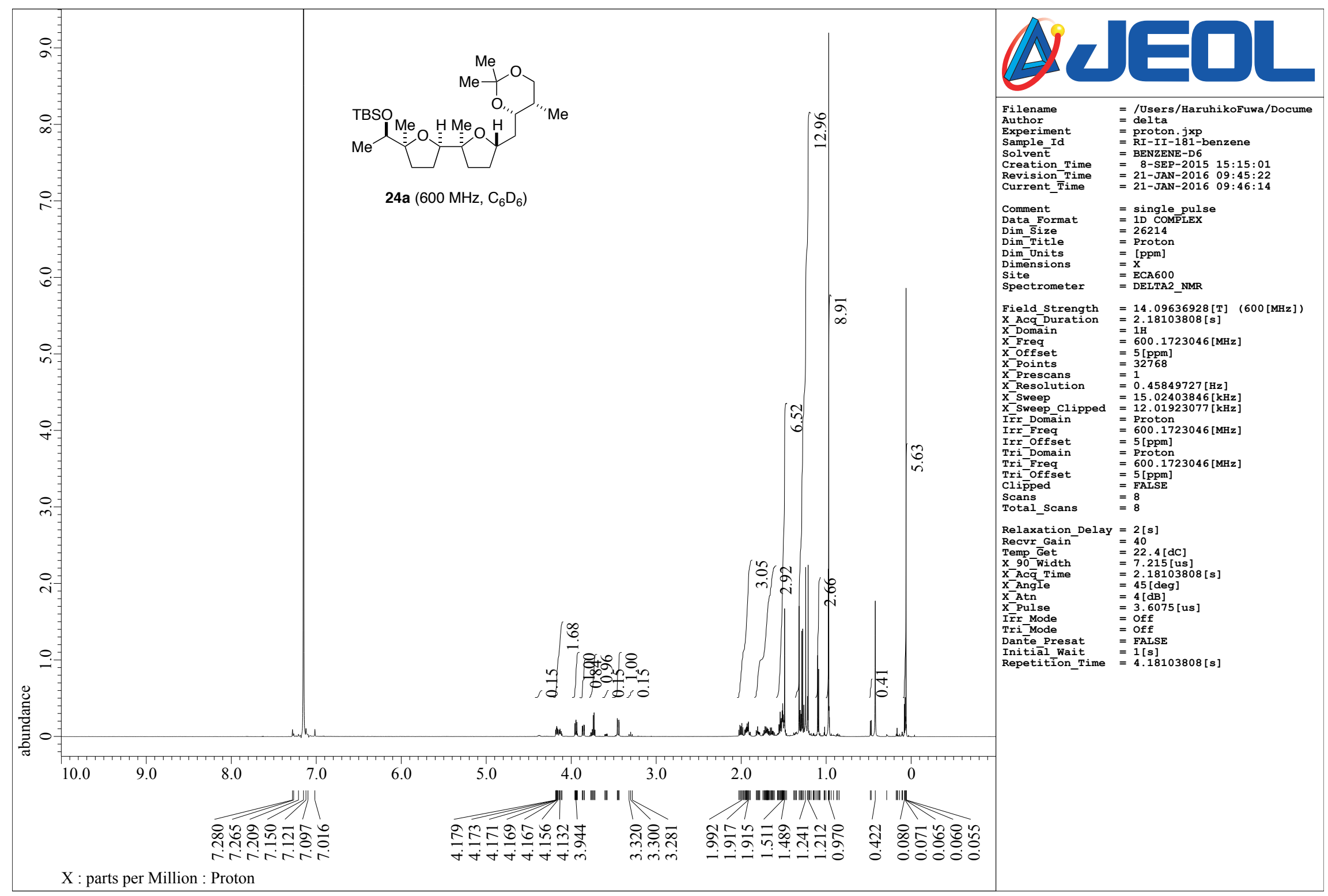




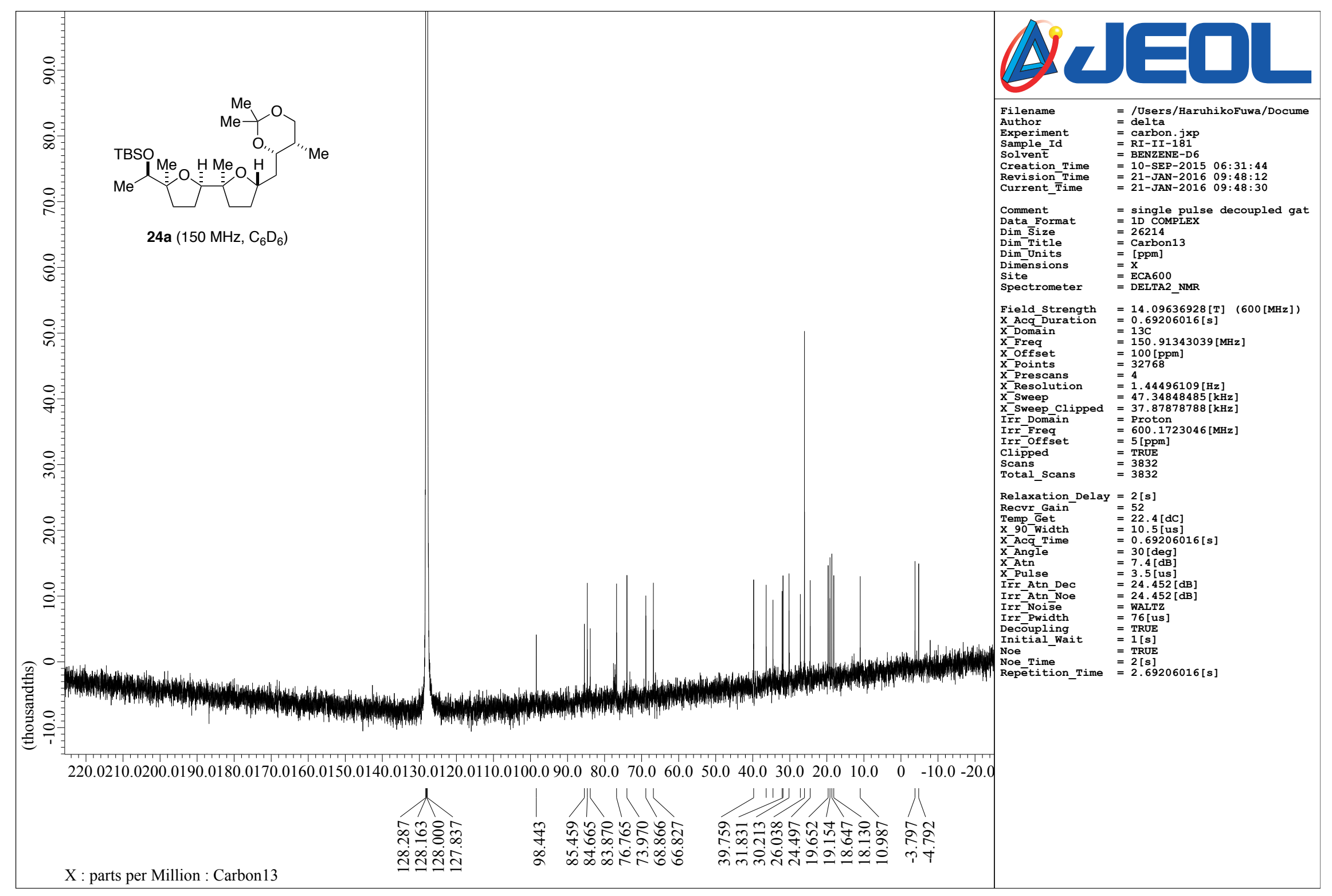




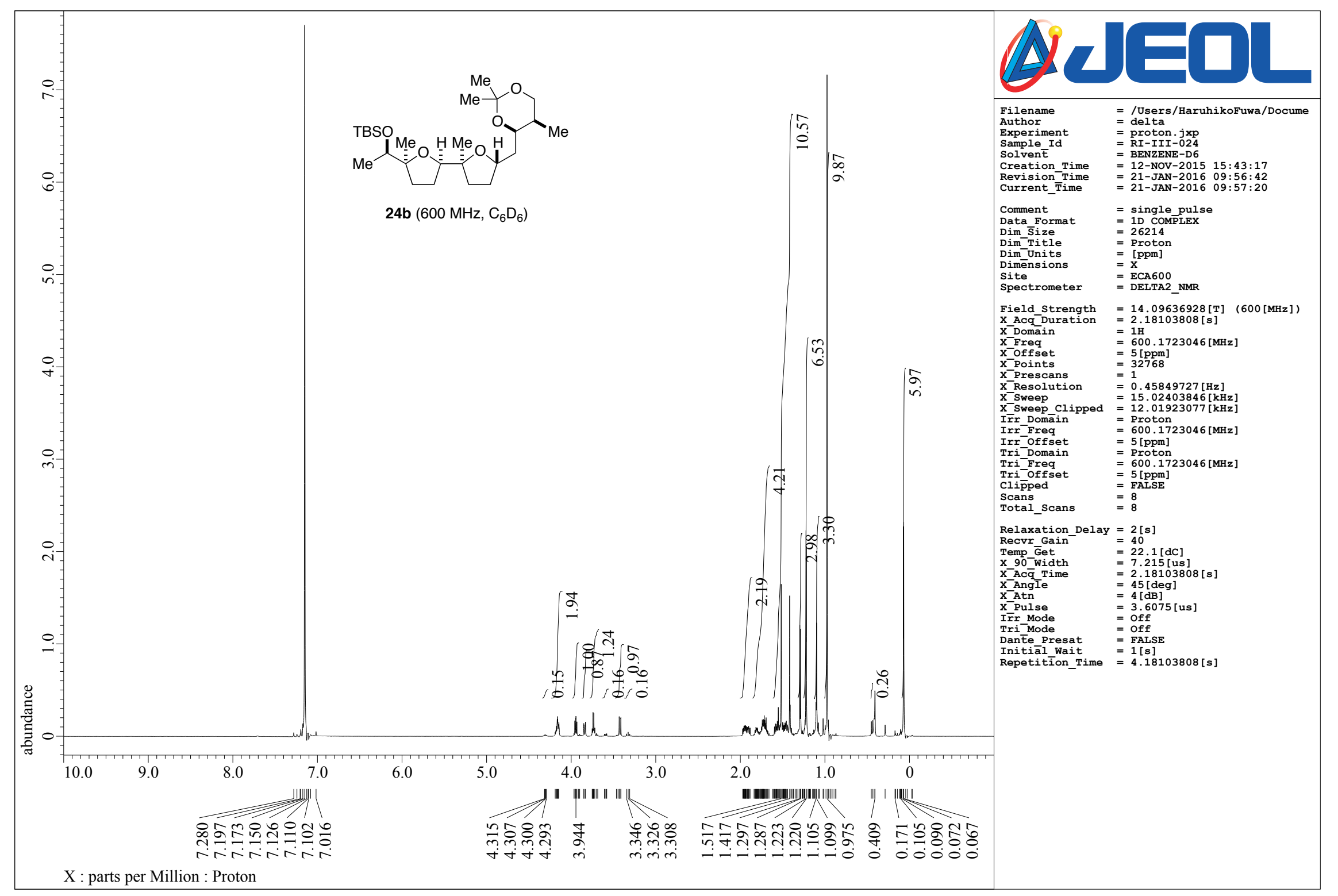




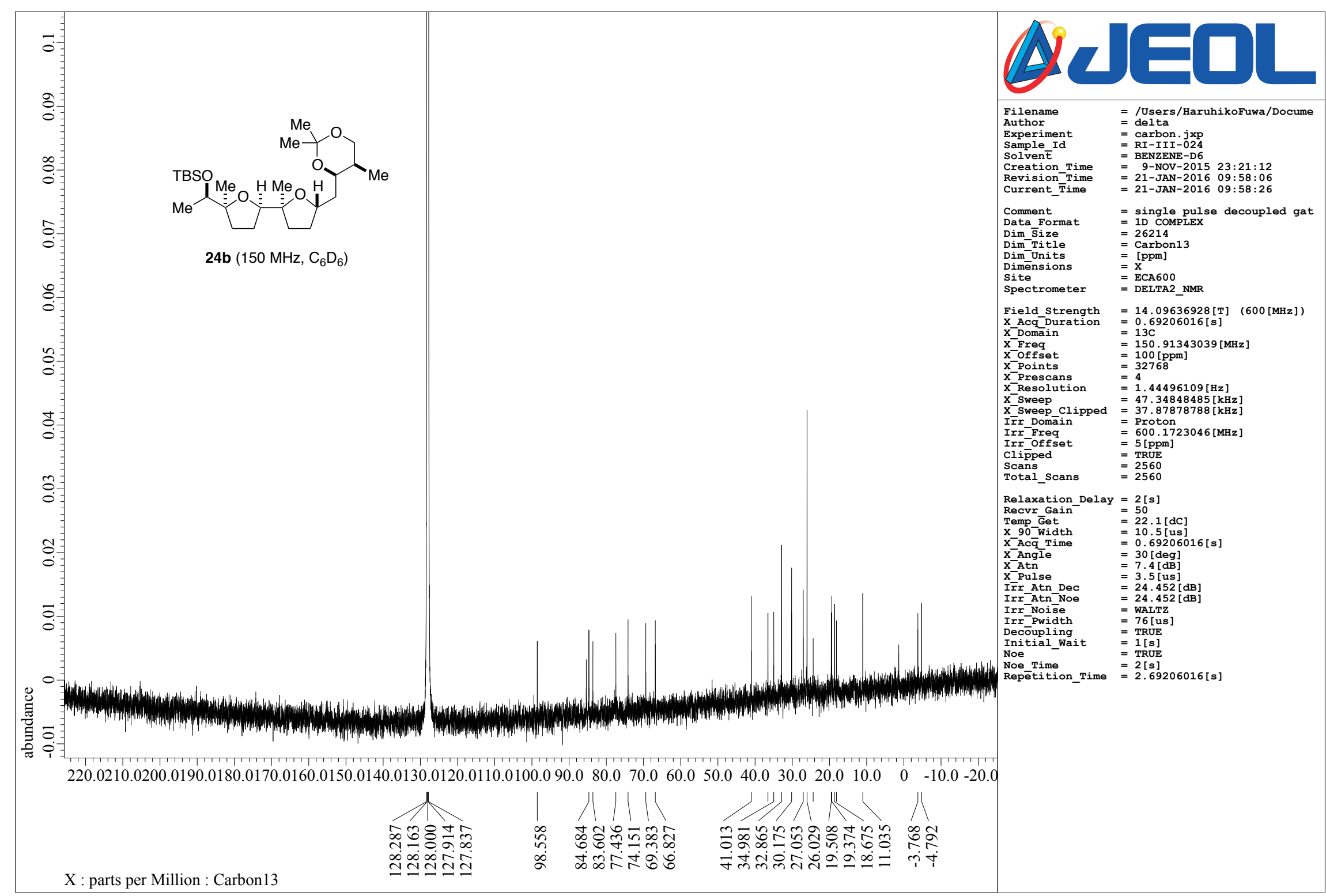




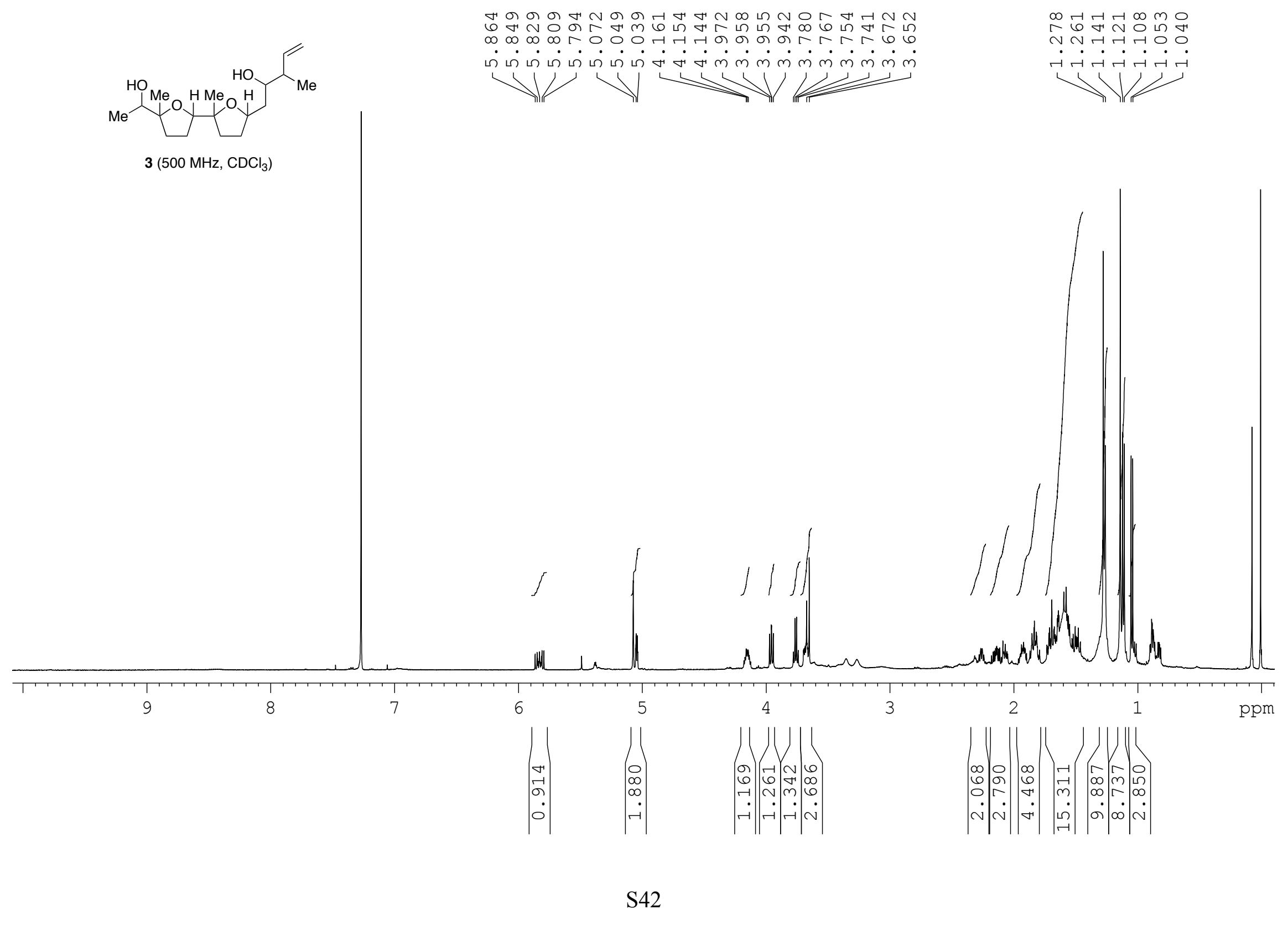




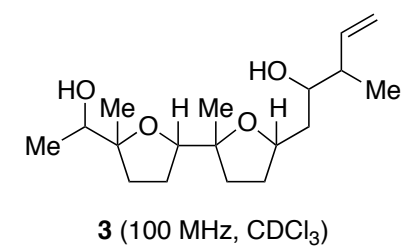

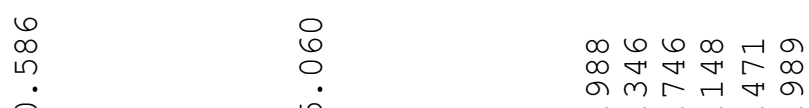

3 $\left(100 \mathrm{MHz}, \mathrm{CDCl}_{3}\right)$

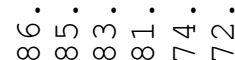

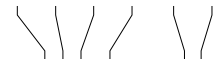

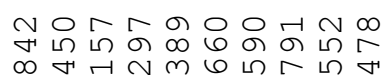

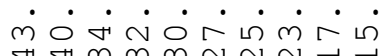

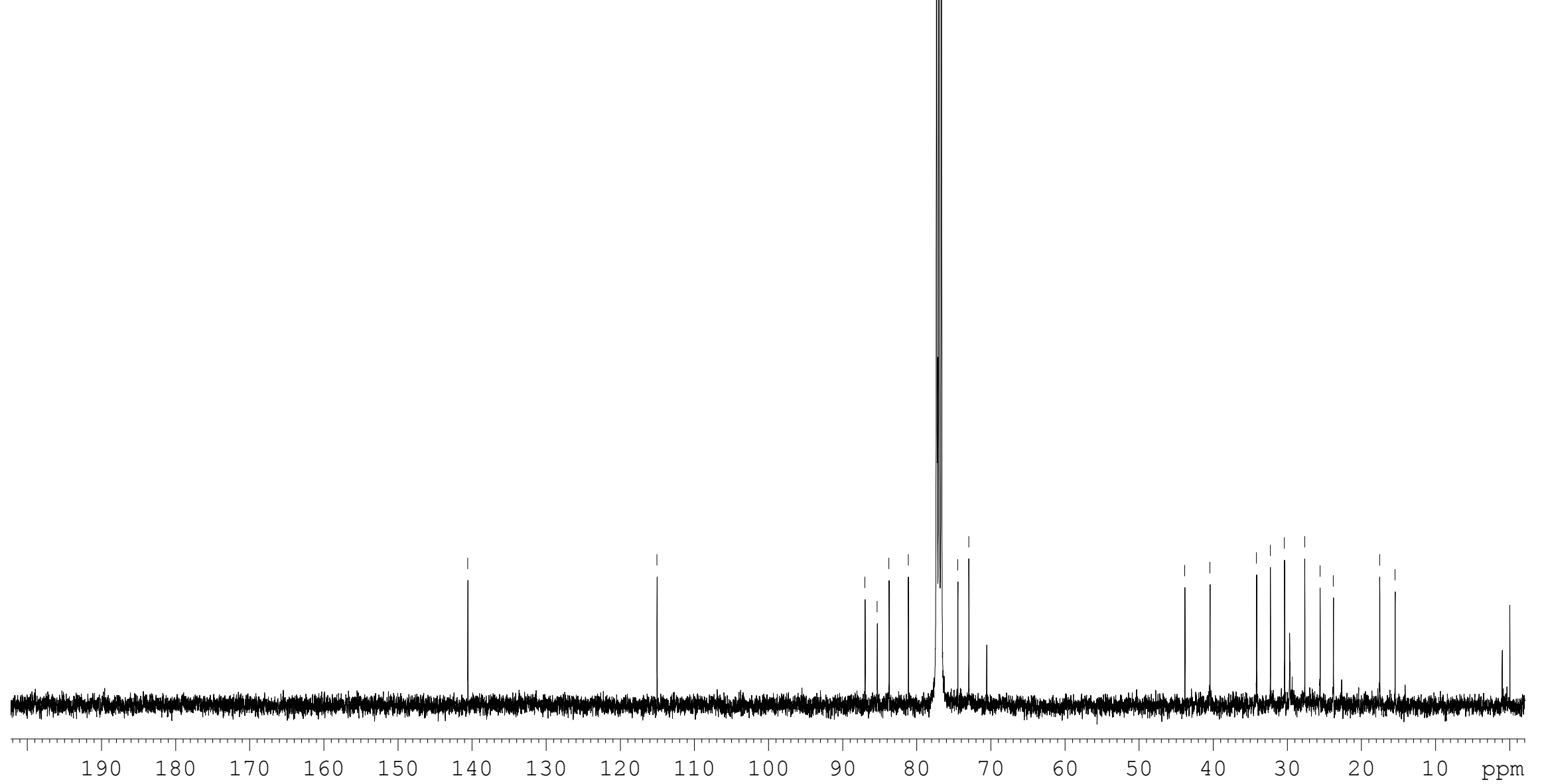




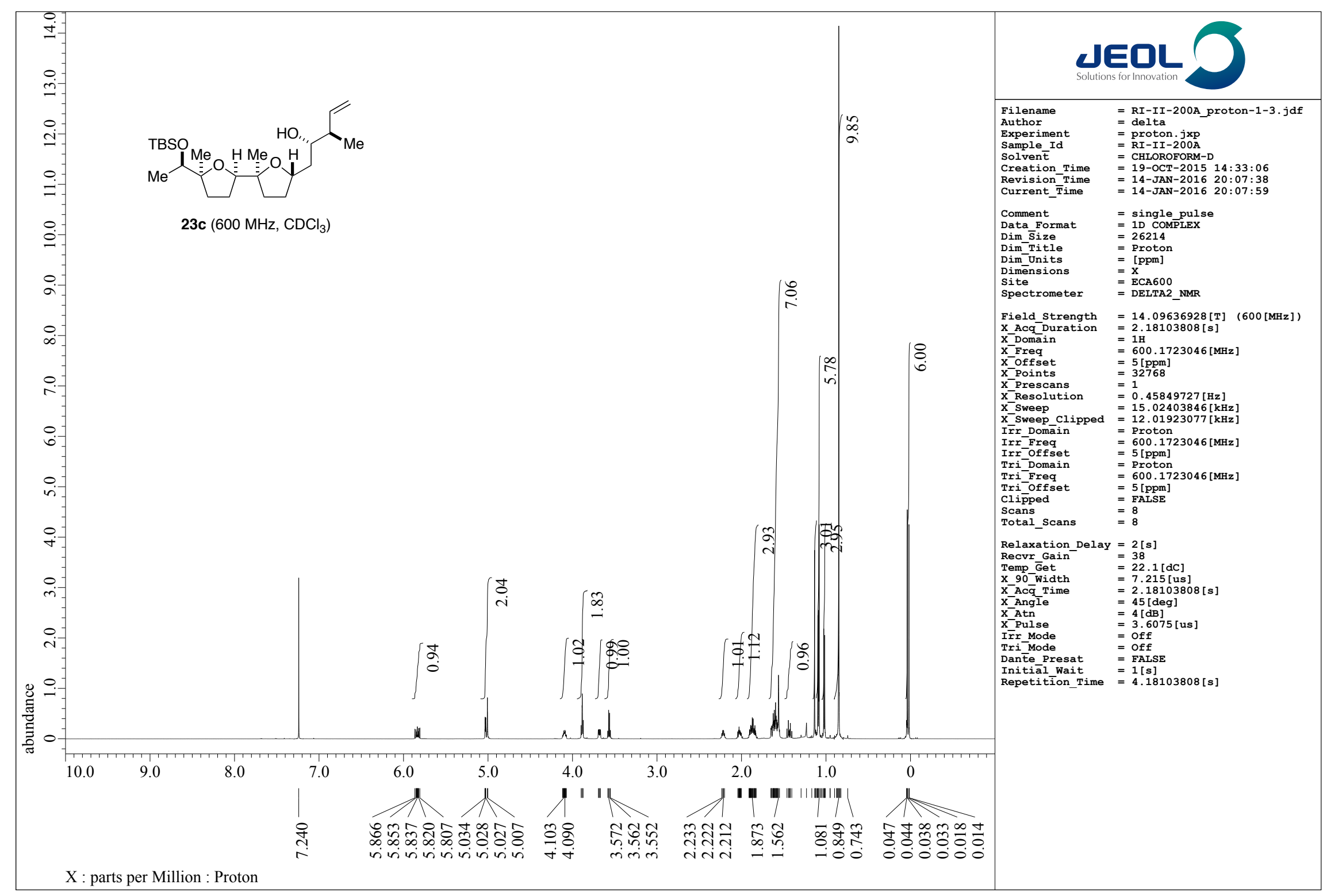




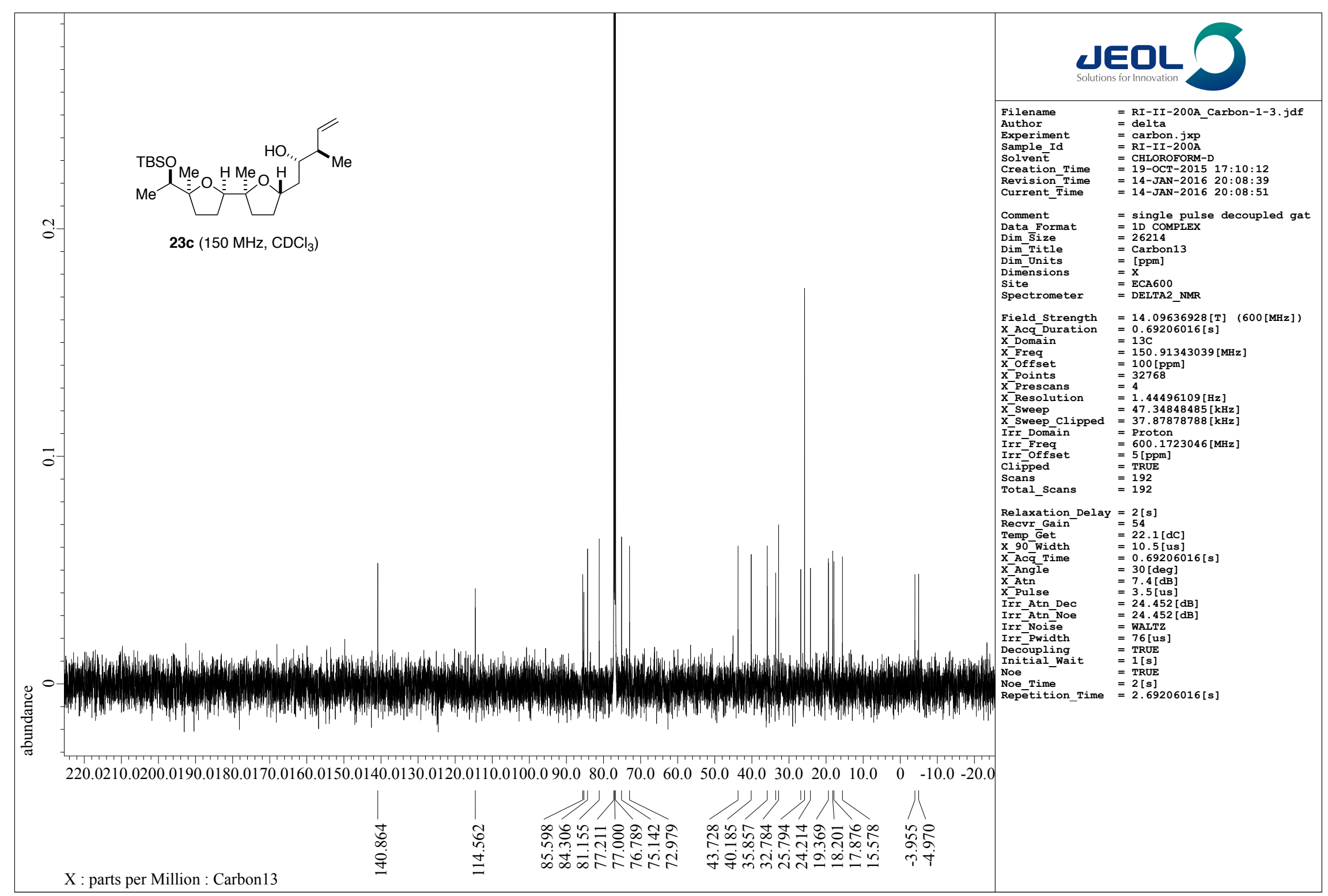




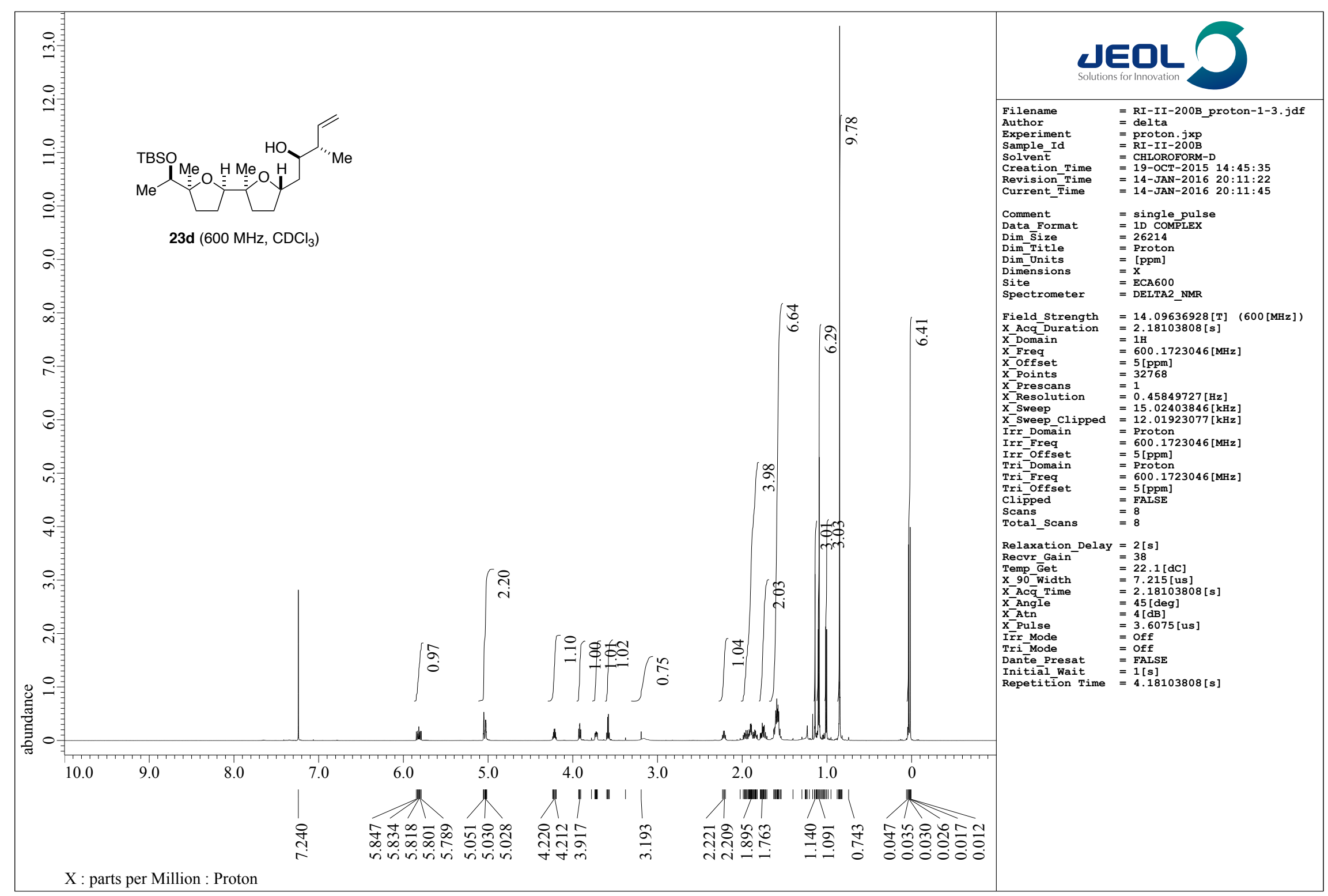




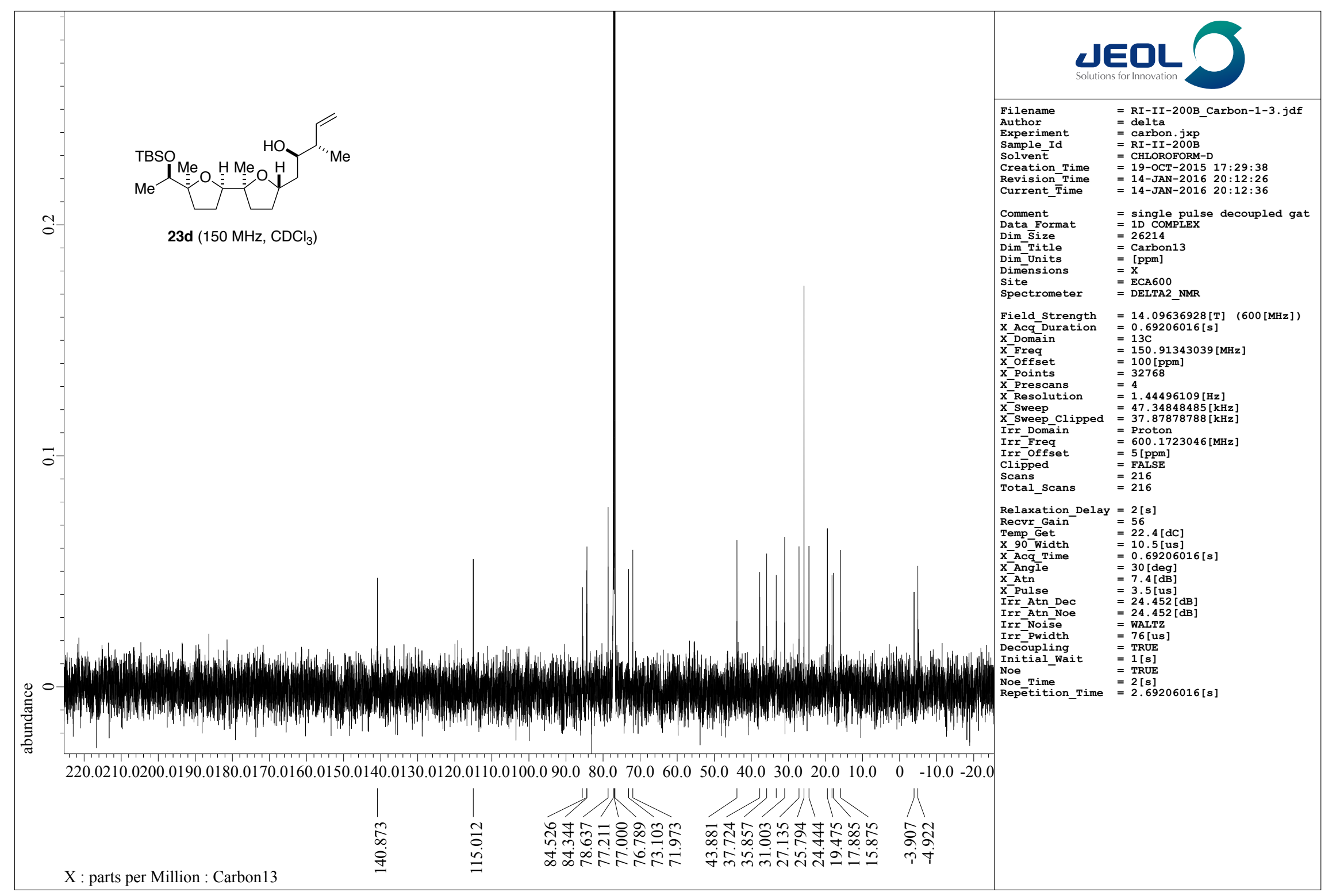




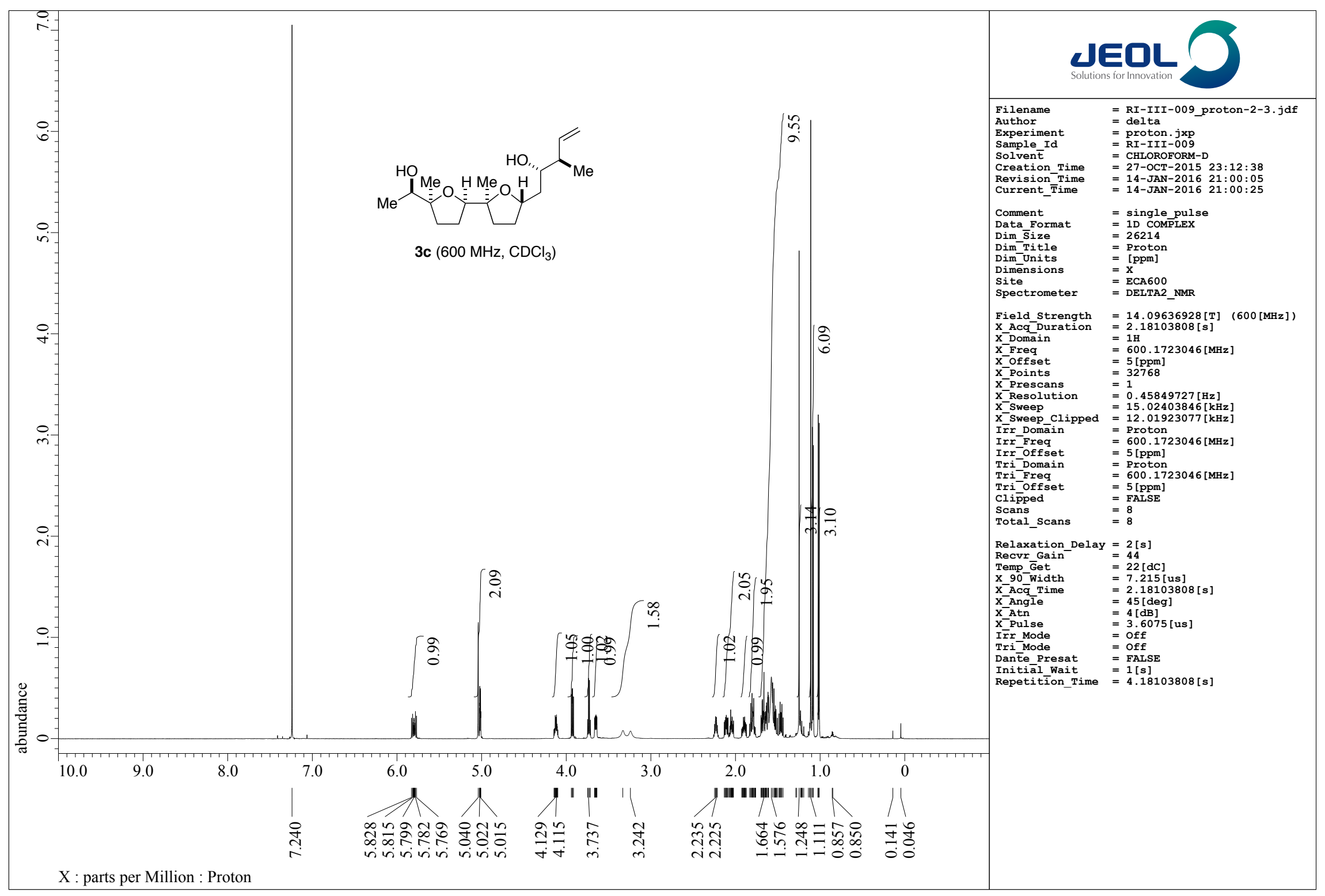




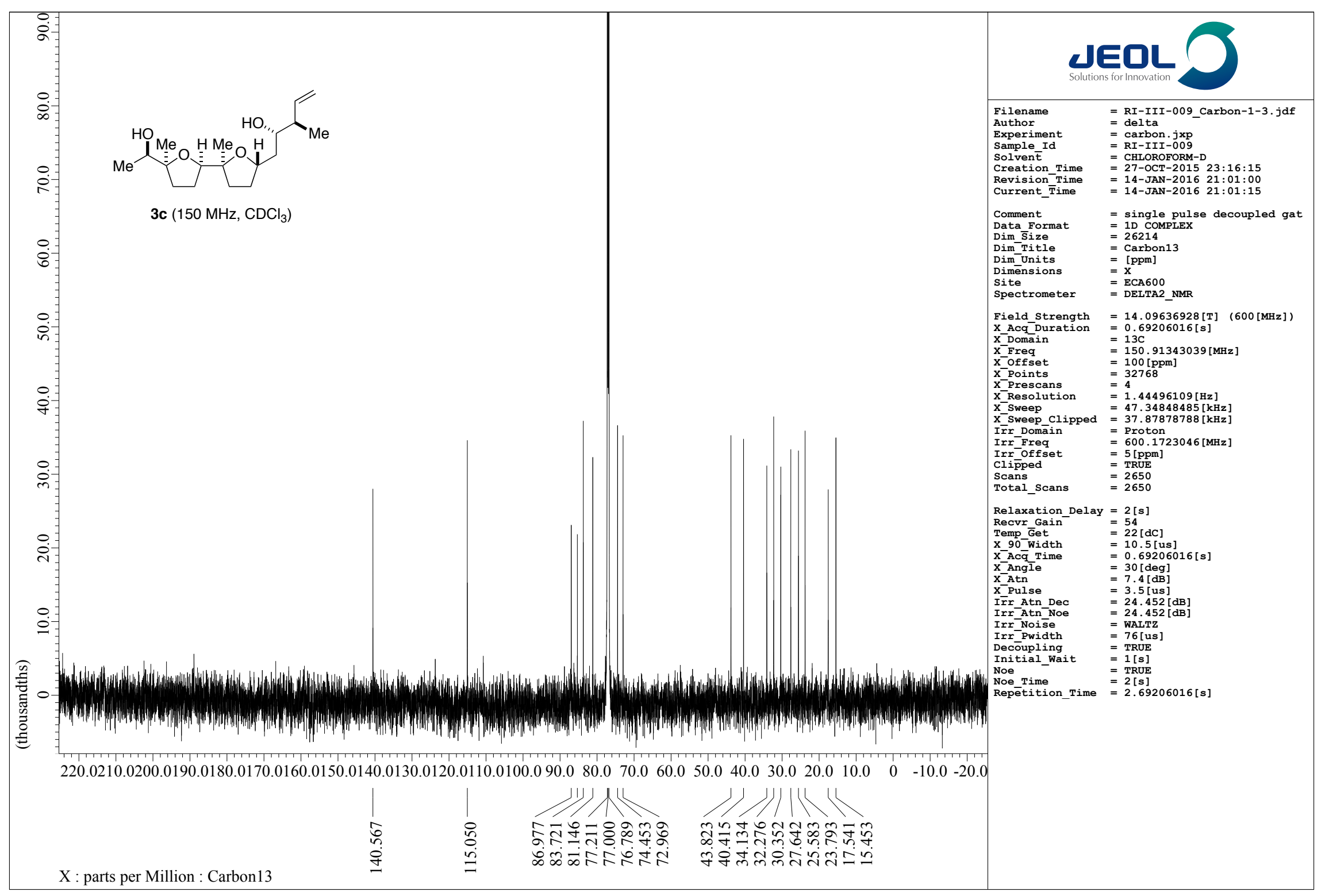




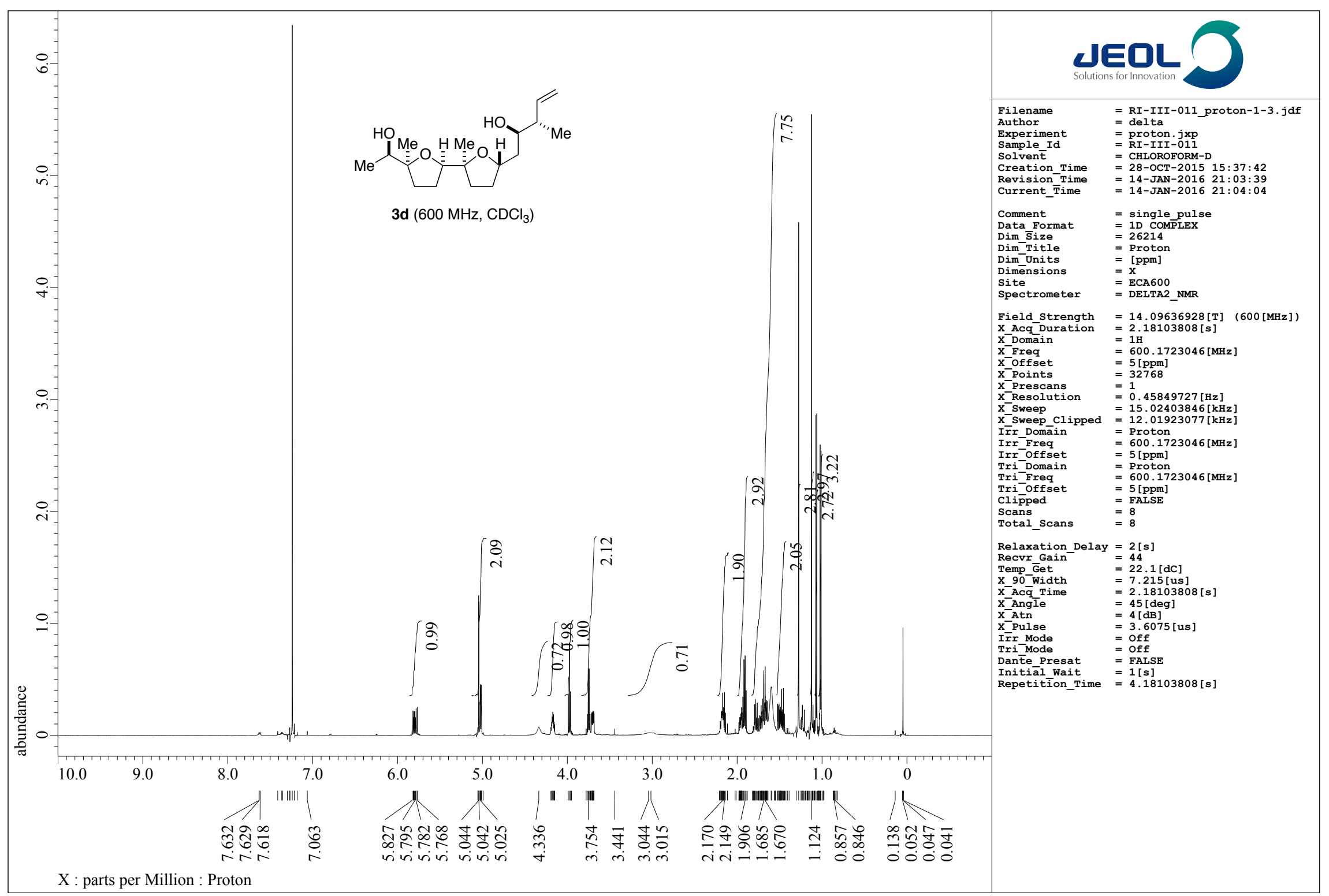




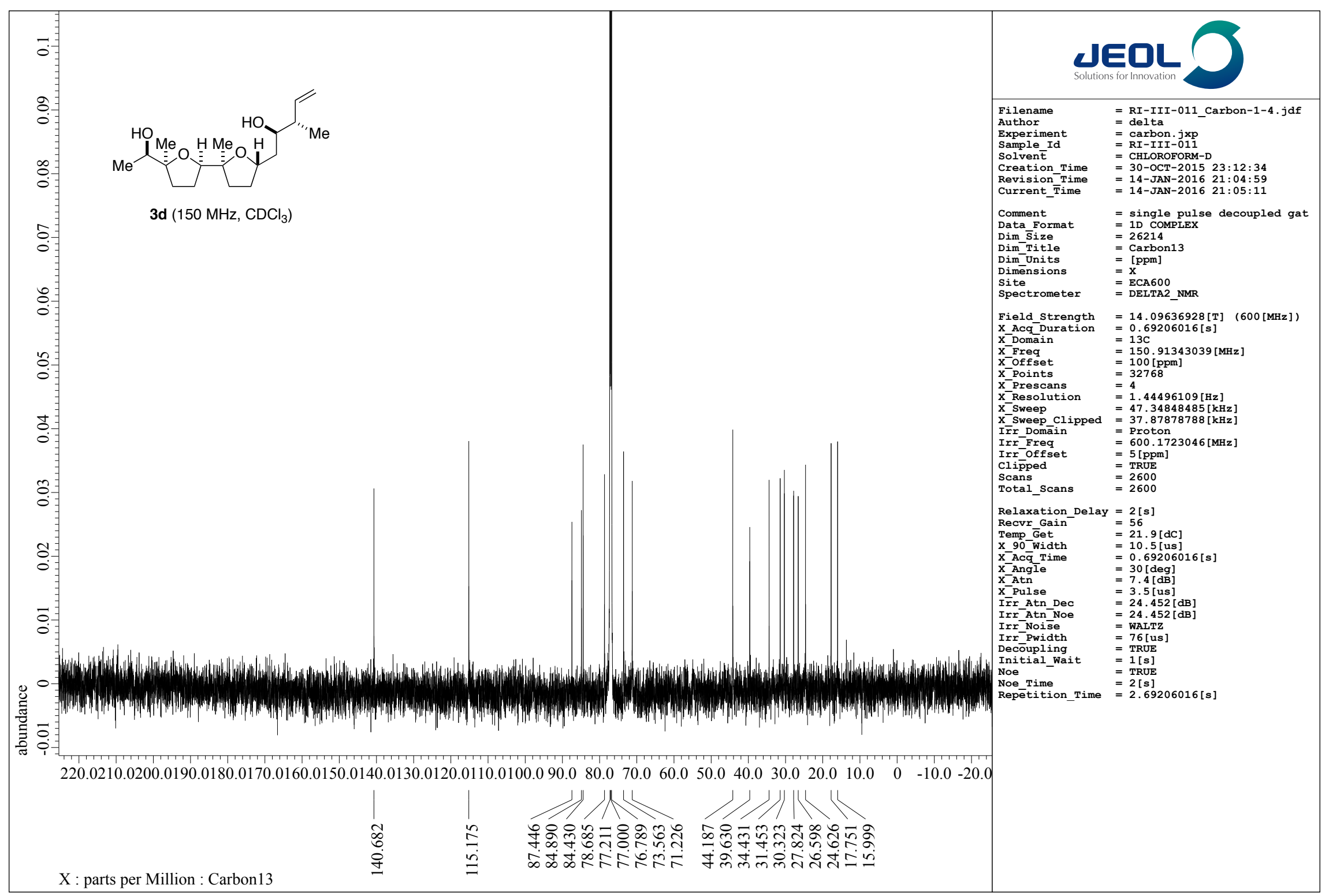




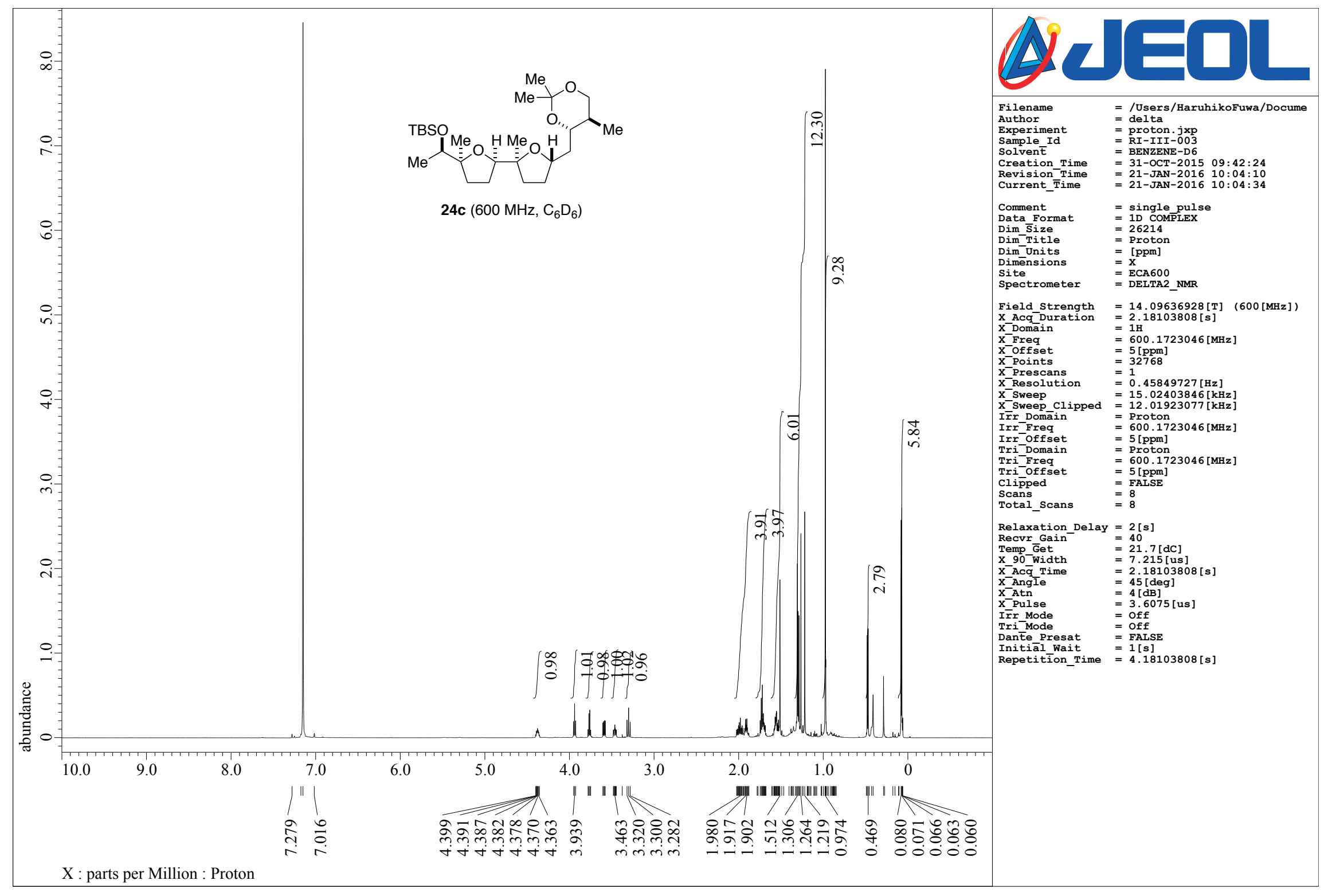




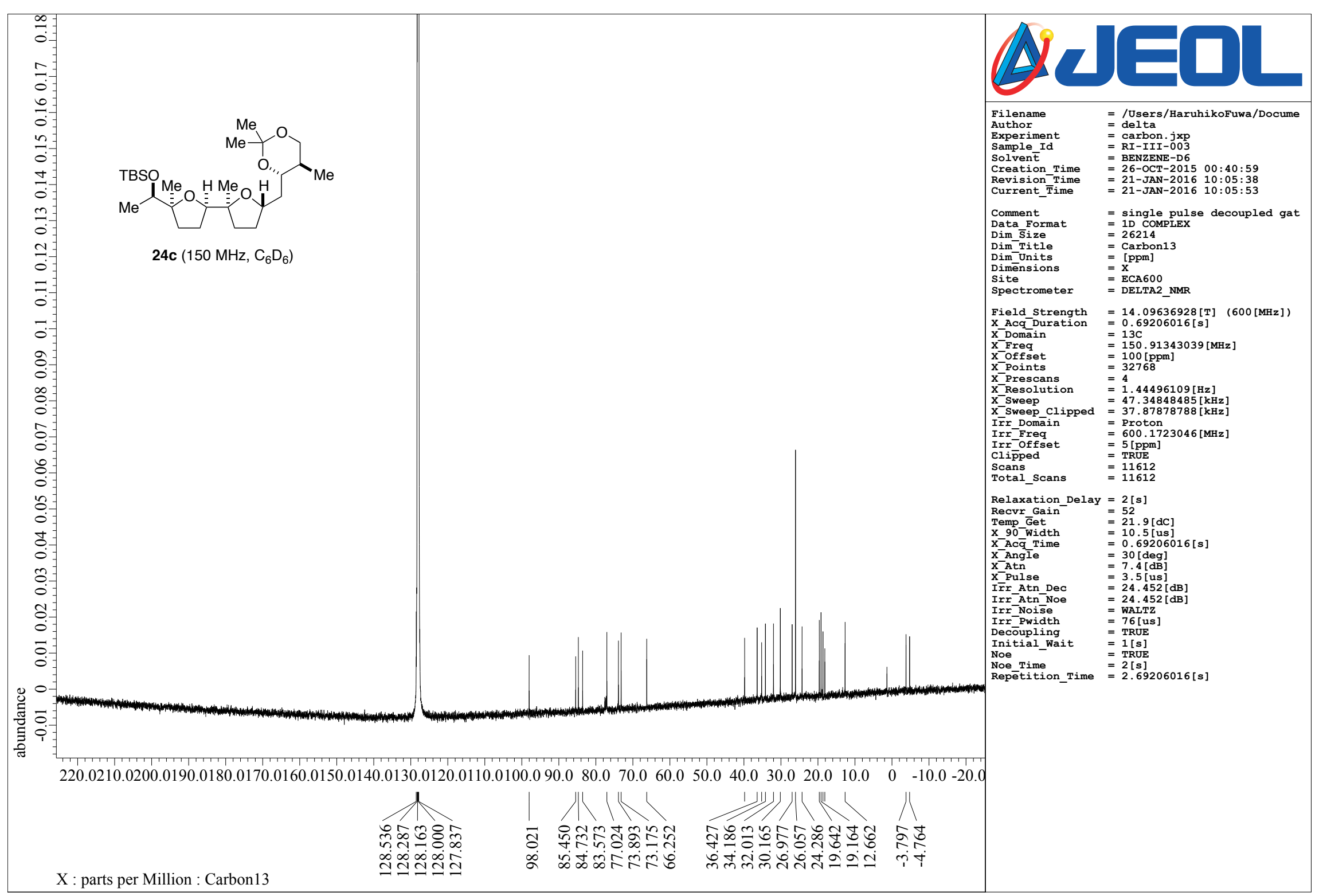




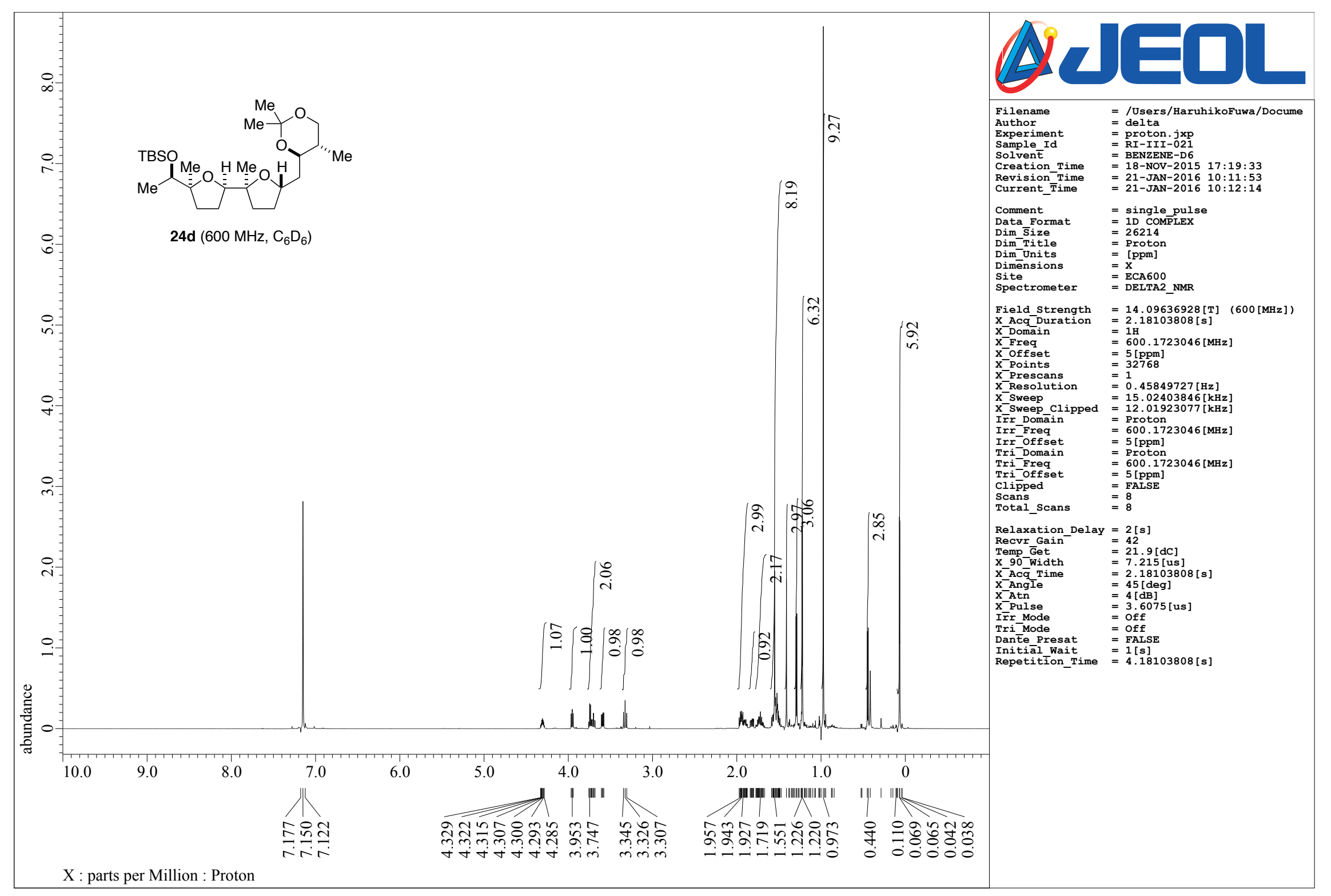




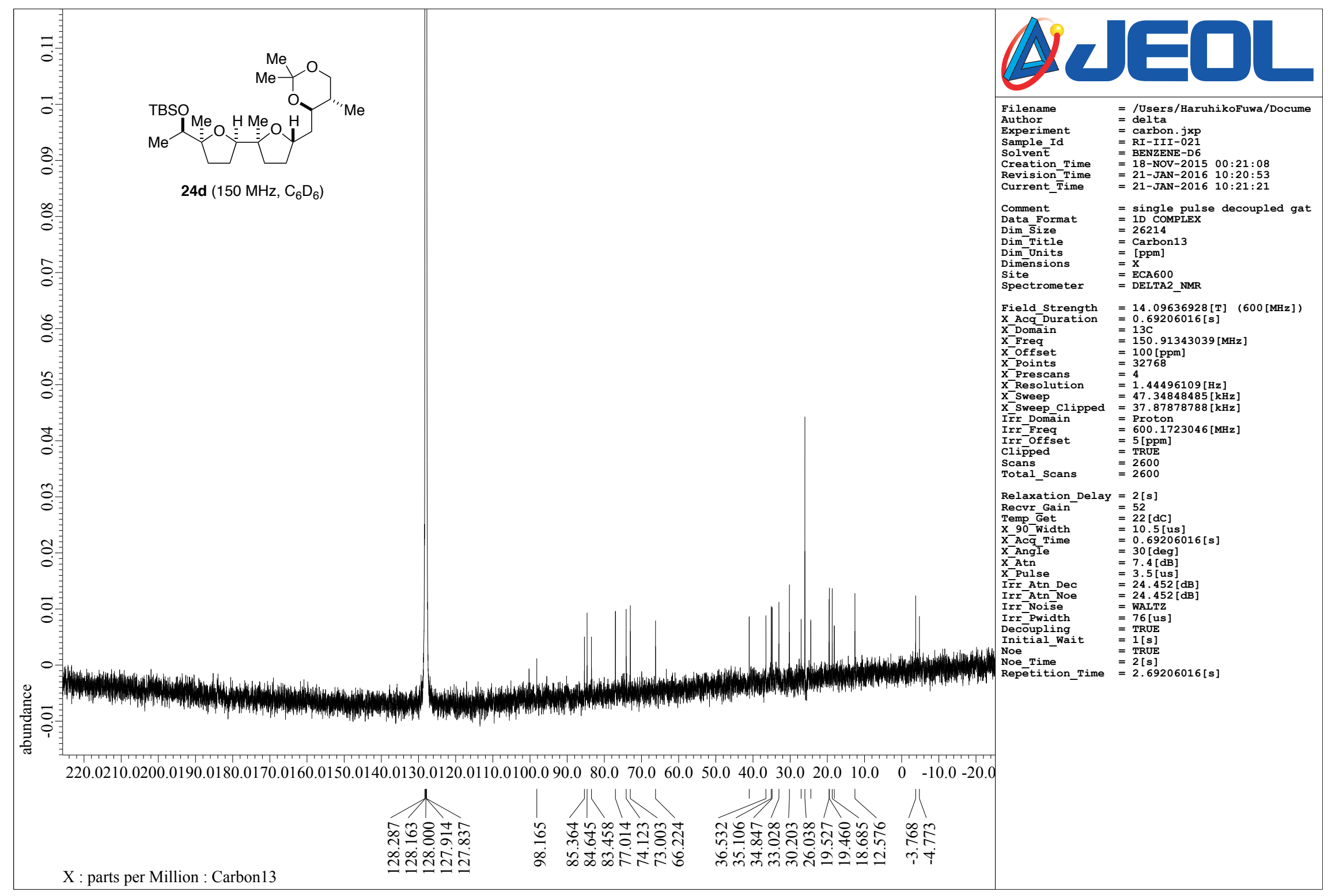

